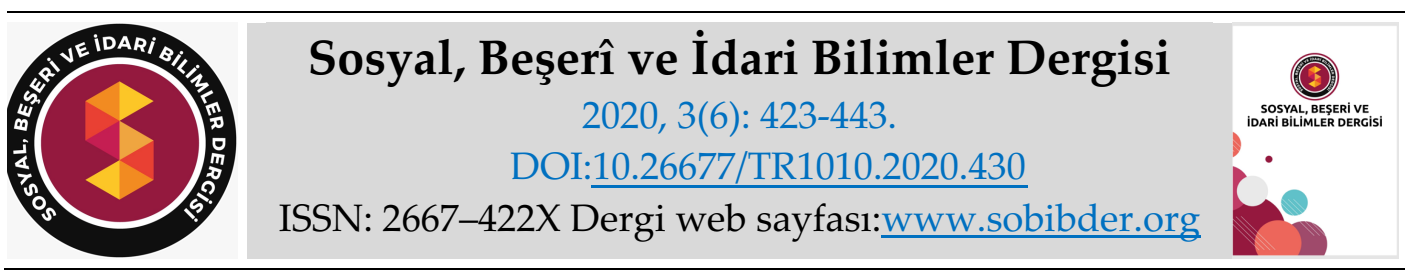

ARASTTIRMA MAKALESI

\title{
1765-1768 Yılları Arası Kadınların Şikâyet Hakkını Kullanımı Üzerine Bir Değerlendirme (3 Numaralı Bosna Ahkâm Defterine Göre)
}

\author{
Ahmet KELEŞ, Yüksek Lisans Öğrencisi, Kırşehir Ahi Evran Üniversitesi, Sosyal Bilimler \\ Enstitüsü, Kırşehir, e-posta: ahmetkeles71@hotmail.com \\ ORCID: https://orcid.org/0000-0002-2131-9614
}

Öz

Şikâyet, kişi veya kişilerin haksızlığa uğradığı veya uğradığını düşündüğü bir konuda bu durumdan kurtulmak için sorunun ilgili kurumlara iletilmesi şeklinde tanımlanabilir. Osmanlı Devleti'nde adaletin sağlanması yönetimi sağlamlaştırmak olarak da görüldüğünden şikâyet hakkının kullanımı noktasında gerek askerilere gerekse de reâyâya önemli haklar tanınmıştır. Toplumun her kesimi en yakınındaki adli mercilere başvurabileceği gibi Divân-ı Hümâyûn'a da şikâyetlerini iletebilmektedir. Bu çalışma da 3 numaralı Bosna Ahkâm defterinden yararlanılarak Bosna'daki kadınların şikâyetlerini Dîvân-ı Hümâyun'a nasıl ve ne şekillerle ilettiklerini, hangi konuları şikâyet ettiklerini, sürecin nasıl işlediğini, kadınlar açısından neleri getirdiğini ve sorunun çözümü noktasında neler yapıldığını incelemektedir. Bu amaçla 3 numaralı Bosna ahkâm defterinin belirlediğimiz yıl aralığını kapsayan hükümleri taranmış ve içlerinden kadınlarla ilgili olan hükümler seçilmiştir. Tespit ettiğimiz hükümlerde kadınların sırasıyla en çok miras, arazi gasbı, gasp (mülk) ve alacak-verecek konularındaki şikâyetlerini Divân-ı Hümâyûn'a intikâl ettirdikleri görülmüştür.

Anahtar Kelimeler: Bosna, Kadın, Ahkâm, Şikâyet.

Makale Gönderme Tarihi: 28.02.2020

Makale Kabul Tarihi: 03.06.2020

\section{Önerilen Atıf:}

Keleş, A. (2020). 1765-1768 Yılları Arası Kadınların Şikâyet Hakkını Kullanımı Üzerine Bir Değerlendirme (3 Numaralı Bosna Ahkâm Defterine Göre), Sosyal, Beşeri ve İdari Bilimler Dergisi, 3(6): 423-443.

(c) 2020 Sosyal, Beşerî ve İdari Bilimler Dergisi. 


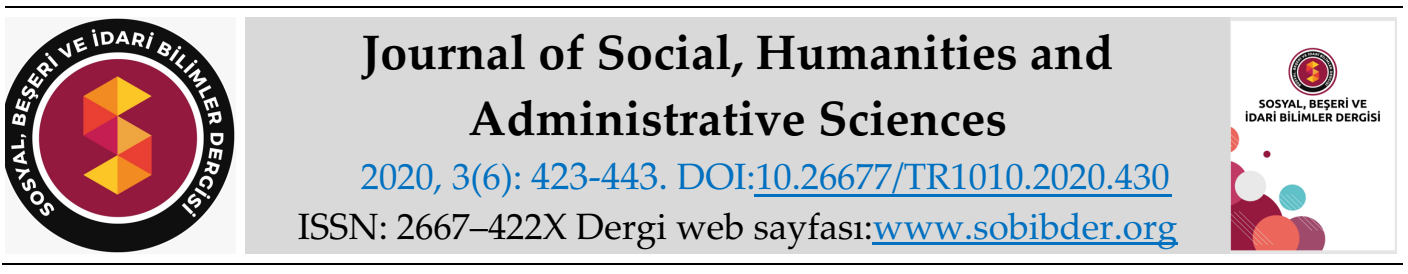

RESEARCH PAPER

\title{
An Assessment on The Use of Women's Right to Complain Between 1765 and 1768 (According to The Bosnia Ahkam Register Number 3)
}

Ahmet KELEŞ, MSc., Kırşehir Ahi Evran University, Social Sciences Institute, Kırşehir, e-mail: ahmetkeles71@hotmail.com

ORCID: https://orcid.org/0000-0002-2131-9614

\begin{abstract}
A complaint can be defined as the communication of the problem to the relevant institutions in order to get rid of this situation in a subject that the person or persons be treated unfairly or feels wronged. Since the provision of justice in the Ottoman state was also seen as consolidating the administration, important rights were granted to both soldiers and the people at the point of exercising the right to complain. Every part of the society can apply to the nearest judicial authorities, as well as convey their complaints to the Divan-1 Hümayun. In this study, benefiting from the documents in the Bosna ahkam book of number 3 It examines how and in what ways women in Bosnia convey their grievances to Divan Humayun, what issues they complain about, how the process works, what it brings for women, and what is done to solve the problem. For this purpose, the provisions Bosna ahkam book of number 3 covering the period of the year we determined were scanned and the provisions concerning women were selected from among them. In the provisions we have determined, it has been observed that the women have received their complaints about heritage, usurping of land, usurping (property) and receivables get over to the Divan-1 Hümayun.
\end{abstract}

Keywords: Bosnia, Woman, Ahkam, Complaint.

Received: 28.02 .2020

Accepted: 03.06.2020

\section{Suggested Citation:}

Keleş, A. (2020). An Assessment on The Use of Women's Right An to Complain Between1765 and 1768 (According to The Bosnia Ahkam Register Number 3), Journal of Social, Humanities and Administrative Sciences, 3(6): 423-443.

(c) 2020 Sosyal, Beşerî ve İdari Bilimler Dergisi. 


\section{Gíriş}

Kadın, dünya üzerinde erkeklerden daha güçsüz, onun boyunduruk ve tahakkümü altında olan bir varlık olarak görülür (Özbay, 2013:185; Açık, 2015:38). Erkeklerin hakim yapısı kadınların erkeklerden yana olan kurallara uymasına neden olmuş, iki cins arasında var olan biyolojik fark, hiyerarşiye dönüşerek toplumsal cinsiyet olarak adlandırılmıştır (Keskin ve Ulusan, 2016:49). Toplumsal cinsiyet kadınlık ve erkeklik arasına bir ayrım koymakta ve kültürden kültüre farklılaşan bu ayrıma göre erkekler kadınlardan daha öncelikli olmaktadır (Keskin ve Ulusan, 2016:50; Y1lmaz, 2012:70). Tarihin farklı dönemlerinde oluşan toplumsal iş bölümü ile erkekler evden uzaklaşmış, kadınlar ise ev ve hane işlerini üstlenmişlerdir (Bayhan, 2016:154). Kadın tarihte gelişen olaylarda değişime sebep olan, sonucu etkileyen değil sonuçtan etkilenen olarak görülmüştür (Gürhan, 2017a:1645). Toplumların yaşamını etkileyen çeşitli olaylar olmasına rağmen kadın ve erkek arasındaki uygulamalar, önyargılar devam etmiştir (Vatandaş, 2007:39). Feminist kuramın gelişmesi ile birlikte kadınlarla ilgili önyargı taşıyan algı kırılmıştır (Göçek ve Baer, 2000:48; Gürhan, 2017a:1646). Feministler, her gerçek kişinin kendilerine eşit davranmasını talep etmiş, erkekler de bunun karşılığını vermişlerdir (Berktay, 2015:41-42). Kadınların tarihine ilgi duyulmaya başlanmış, kadınlarla ilgili çeşitli çalışmalar yapılmıştır (Gürhan, 2017a:1646). Kadınlarla ilgili yapılan bu çalışmada ise Osmanlı Bosna'sında yaşayan kadınların sosyal yaşamda karşılaştıkları sorunlar karşısında hak arama sürecine, bu süreç sonunda nasııl karşılık bulduklarına, kendilerine çözüm noktasında kimlerin yardımcı olduklarına, Divân'a başvururken hangi yöntemleri tercih ettiklerine dair bir değerlendirme yapılmaya çalışılacaktır.

Osmanlı kadınları ile ilgili bugüne kadar çeşitli çalışmalar yapılmıştır. Faroqhi, Jennings, Gerber gibi yabancı tarihçiler Ankara, Kayseri ve Bursa kadı sicillerinden yararlanarak kadının Osmanlı'da hukuk sistemi açısından etkinliğini araştırmışlardır (Akyüz, 2007:76). Osmanlı hukukunda kadın-erkek eşitsizliği bulunmaktadır. Bu durum sadece Osmanlı'ya özgü olmayıp geleneksel toplumların genelinde görülmektedir (Berktay, 2015:98). Osmanlı'da kadın reşit olduktan sonra hukuki olarak bir kimlik sahibi olmuş, evlendikten sonra mallarının sevk ve idaresini ele alabilmiş, ticarete atılarak bu işler için kendisine vekil tayin edebilmiştir. Eşlerine kefil olmalarının yanında sosyal ve toplumsal alanda var olabilmişlerdir (Iş̧ı, 2018:29).

Osmanlı Devleti'nde şikâyet hakkının kullanımı ise kadın ve erkekler arasında ayrım gözetmeksizin tanınan haklardan biridir. Devletle toplumun iletişim kurması (Tuğluca, 2012:108) olarak adlandırılabilecek bir mekanizma olan şikâyet hakkının kullanımını adaletin yerine getirilmesi noktasında devlet yönetimi de oldukça önemsemiştir.

Osmanlı Devleti, örgütlenmesini İslam hukukuna dayandırdığından çeşitli kaynaklardan beslenmiştir. Bulunduğu coğrafya ve kültür ile eski Türk geleneği bu örgütlenmeyi besleyen kaynaklar olmuştur (Öz, 2017:55; Taş, 2007:187). Bu örgütlenme çerçevesinde Kınalızade Ali toplumun dengeli bir yaşam sürmesi için unsurlar arasında adaletli olunmasını ve bir hükümdarın var olması gerektiğine işaret eder (Suzuki, 1987:376). Buradan bahisle hükümdar iktidarının devamını sorunsuz bir şekilde sağlamak için de şikâyet hakkını tanımıştır.

En temel çerçevede şikâyet hakkı reâyâ veya devlet kademesindeki askerilerden birinin haksızlığa uğradığı anda ilk başvuru yaptığı mahkemede sorunun çözülememesi üzerine Divân1 Hümâyûn'a başvurması yani direk şikâyetini padişaha iletmesidir (Taş, 2007:189).

Osmanlı Devleti merkezileşmeyle birlikte kurumlarıyla bir ağ meydana getirdiği ilk andan itibaren 17. yüzyıla kadar şikâyetler mühimme defterlerine kaydedilmiştir. Mühimme defterleri içerisinde imar, iskan, siyaset, askeri tarih gibi konuların yanında divana yansıyan şikâyetleri de barındırmıştır. 17. yüzyılda mühimme defterlerine kaydedilecek konular konu bazlı farklı defterlere kaydedilmeye başlanmıştır. İnalcık (İnalcık, 1988:34), bu defterlerin Ecnebi, Name, Şikâyet, Ahkâm ve Nişan defterleri olduğunu belirtir. 1648 yılında meydana gelen 
bürokratikleşme neticesinde şikâyet defterleri oluşturularak şikâyetler ayrı defterlere kaydedilmeye başlanmıştır (Emecen, 2005:124; Emecen, 2011:131).

Şikâyet defterleri, 1648-1823 yılları arasında tutulmuş olup, toplam 208 adettir. (Özel, 1988:551) $\mathrm{Bu}$ defterler, merkez ile taşra arasındaki ilişkilere dair mühimme defterlerinin eksik kaldığ noktaları tamamlayabilmektedir. Şikâyet kâyıtları çoğunlukla devlet görevlilerinin hukuki rolleri, suçların çeşidi, şikâyetçilerin sosyal ve coğrafi dağılımı hakkında önemli bilgiler sunmaktadır (Kovacs, 2012:275).

Reâyânın kendi arasındaki şikâyetleri daha çok mahalli mahkemelerde hallettiği bilinmektedir. Bu durum şikâyetlerin Divân'a intikâlinde sayısal olarak bir düşüşe neden olmakta, sadece mahalli mahkeme veya yönetim tarafından çözülemeyen hukuki ve idari ihtilaflar merkeze iletilmekte ve bununla ilgili alınan kararlar ise şikâyet defterlerinin konusunu oluşturmaktadır (Gümrükçüoğlu, 2012:186).

Ahkâm defterleri ise 17. yüzyılda oluşturulan şikâyet defterlerinin iyileştirilmiş bir biçimi olarak tarif edilebilir. Bu iyileştirme Divân'a ulaşan şikâyet sayısında artışın olduğu anlamına gelmektedir. Zira orta büyüklükteki merkezlerden, küçük bir bölgeye kadar bu defterlerin tutulmasına izin verilmiştir (Faroqhi, 2000:13).

Ahkâm, Arapça hüküm kelimesinin çoğulu olup, kesin emir ve karar anlamına gelmektedir. Şikâyet defterlerinden şeklen daha uzun ve dar olan ahkâm defterleri şikâyetlerin artmasına paralel olarak Reisü'l-küttap Ragıb Efendi'nin bölgelere göre tasnif sistemini getirmesi ile ortaya çıkmıştır (Şimşir, 1994:358-361). İçerik olarak eyâlet ahkâmları mahallinde halledilemeyen sorunların artması ve bunların merkeze aksettirilmesi neticesinde bürokratik muamelenin kolaylaştırılması amacıyla oluşturulmuştur. Özel olarak eyâletler için ahkâm defterleri oluşturulmasına rağmen, şikâyet defterleri de tutulmaya devam etmiştir (Emecen, 2005:125; Emecen, 2011:132). 1839 tarihine kadar tutulmaya devam eden ahkâm defterleri Sivas, Anadolu, Şam, Trabzon, Diyarbekir, Karaman, Halep, Adana, Maraş, Rakka, Erzurum, Silistre, Özi, Rumeli, Bosna, Mora ve İstanbul'a aittir (Sahillioğlu, 1988:551).

Yaptığımız bu çalışmada 3 numaralı Bosna ahkâm defteri yıl bazlı sınırlandırılarak belgelerdeki kadınların şikâyetlerine odaklanılmaktadır. Bosna ahkâm defterleri 9 adet olup içlerinde en fazla sayfaya sahip olan defter 3 numaralı Bosna ahkâm defteridir. 1765-1778 yıllarını kapsayan defter toplam 404 sayfadır. Çalışmanın yıl aralığı olan 1765-68 yılları arası 120 sayfa 325 belge/hüküm içerisinde gasp, miras, vakıf, arazi ihtilafları, vergi, zulüm, alacak-verecek gibi konularda yapılan şikâyetleri ihtiva etmektedir.

\section{DEVLET-TOPLUM İLIŞKİLERİ BAĞLAMINDA ŞİKÂYET HAKKI KULLANIMI ve OSMANLI'DA ŞİKÂYET MEKÂNIZMASI}

Osmanlı Devleti'nin, şikâyet hakkı ve bu hakkın kullanımına verdiği önem devlet-toplum anlayışı ve İslam hukukundan ileri gelmektedir (Tuğluca, 2016:17-18). Bu anlayış çeşitli kaynaklardan beslenmiştir. Bunlar, Orta Asya Türk geleneği ve Yakındoğu devletlerinin yönetim anlayışıdır (Öz, 2017:55-56). Yönetim için çeşitli fakihler ve filozoflar devletin varlığına ve bir hükümdarın mutlak surette bulunması gerektiğinde hemfikirdirler. Devlet, dini ve dünyevi işlerin yapılmasında, insanların birbirlerine bağımlı olması noktasında kilit rol oynamaktadır (Tuğluca, 2016:18).

Osmanlı toplum yapısı, klasik İslam düşüncesinde erkân-ı erba'a ile organik toplum modeli çerçevesinde ele alınmıştır. Bu model de toplum temelde yöneten yönetilen, pratikte dörde ayrılmıştır. Bunlar kılıç, kalem, çiftçi ve tüccar/zanaatkarlardır. Sultanın görevi bu tabakalar 
arasında adaletli bir şekilde hüküm vermektir. Tursun Bey, sultanı adaletin faziletli bir koruyucusu ve daima zulüm ve bâtıl olana baş eğdiren olarak tanımlar. ${ }^{1}$ Kınalızâde ise, adaletin en şerefli fazilet olduğunu ve üç şeyde adalete dikkat edilmesi gerektiğini belirtir. ${ }^{2}$ Sultanın adaletli olması noktasını dönemin düşünürleri daire-i adliye olarak ifade etmişlerdir. Bu formülasyonda, ordusuz hükümdar olmaz, malsız ordu olmaz, tebaa olmadan mal elde edilmez ve adalet olmayınca da tebaa olmaz şeklinde açıklanmıştır. Her şeyin temelinin yine adalet olduğu vurgulanmıştır (Tuğluca, 2016:19).

Adalet'in sağlamasına oldukça önem veren Osmanlı Devleti, Türk-İslam geleneğinden birçok müesseseyi alırken, mezalim mahkemesini doğrudan almamış ve şikâyet dinlemek için çeşitli mercilere yetki vermiştir. Veziriazama bağlı olan Çarşamba, Cuma ve İkindi divanlarında da şikâyetler dinlenmiştir. Osmanlı Devleti'nde yaşayan herkes şikâyetlerini en yakınındaki adli merciiye iletebileceği gibi en üst düzey yargı mercii olan Divân-1 Hümâyûn'a da iletebilirdi. Şikâyetin önemi, sorunun büyüklügü̈, başvuruda bulunan kişinin toplumsal ve ekonomik konumuna göre bu merciilerden birisi tercih edilmiştir (Tuğluca, 2016:29-31). Divân-1 Hümâyûn, siyasal otorite ile yakından ilişkili olduğundan halk nezdinde daha fazla kabul görüyor ve sultanın adaletini sağliyordu (Shahr, 2000:243).

Şikâyeti olanlar başvurularını bizzat yapabileceği gibi yakınma dilekçesi (arzuhal) ile de olabilirdi. Dilekçeleri bizzat padişaha verebilmek Divân'da görüşülme şansını önemli ölçüde artırırdı. Daha çok cuma namazına gidiş-geliş esnasında dilekçeler sultana sunulabilirdi (Mumcu, 2007:79-80). Divan'dan bağımsız padişahın şikâyet dinlemesine örnek olarak Yıldırım Bayezid verilebilir. Sabahları yüksek bir yere oturarak, şikâyeti olanlar ona başvurur sorunu hızlı bir şekilde çözülürdü. Hizmetinde bulunanlara hıyanette bulunmamalarını söylerdi (Şevkiye İnalcık, 1948:192; Tuğluca, 2016:31-32).

Divân'da ilk olarak dış devletlerle ilgili konular görüşülürken, daha sonra iç meseleler ve tayin ve terfiler görüşülürdü. Ardından şikâyetlerin dinlenmesine sıra gelirdi (Tuğluca, 2016:35-36).

\section{Kadınların Şikâyet Hakkını Kullanımı}

Çalışmanın amacı Bosna Eyâleti'nde yaşayan veya daha önce burada yaşamış kadınların şikâyet hakkını kullanımını 3 numaralı Bosna ahkâm defterinden yararlanarak açılamaktır. 325 belge içerisinde kadınlarla ilgili şikâyet eden-edilen toplam hüküm sayısı 27'dir. Şikâyet hakkını kullanarak Divân'a başvuru yapan 18 kadın şikâyetçi konumundadır. Bu 18 belge içerisinde 5 belgede hem şikâyet eden hem de edilen taraf kadınlardır. ${ }^{3}$ Bu 5 belge her iki taraf içerisinde de

\footnotetext{
1 Tursun Bey, "Ölçüsü düzgün olmayan terazi iyi tartmaz, çeliği iyi dövülmemiş kılıç işe yaramaz, güzel olmayan söz sonuç vermez, amelsiz ilmin neticesi olmaz ve adaletsiz ülke bâki kalmaz" diyerek bir ülkede adaletin en temel nokta olduğunu vurgulamıştır. Tursun Bey, Tarihi Ebu'l-Feth, haz. Ahmet Tezbaşar, Tercüman 1001 Temel Eser, s. 27.

2 Bunlar, malların taksimi, muamelede adalet ve had, siyaset ve kisasta adalet. Ayrica, toplum hayatında zalim kişilerin görüleceğini, bunun içinde adil bir otoritenin bulunmasını ve zulmü önleyerek hakkın yerine getirilmesi gerektiğini vurgulamıştır. Kınalızâde Ali, Ahlâk-1 Alâ-i, haz. Hüseyin Algül, Tercüman 1001 Temel Eser, s. 135, 137-138.

${ }^{3}$ Hem şikâyet eden hem de edilenin kadın olduğu belgeler şunlardır. Bâb-1 Asâfî Dîvân-1 Hümâyûn Sicilleri Dizisi, Bosna Ahkâm Defterleri, 3 Numaralı Bosna Ahkâm Defteri, Sayfa No: 25, Hüküm No: 2, Sayfa No: 41, Hüküm No: 1, Sayfa No: 86, Hüküm No: 3, Sayfa No: 99, Hüküm No: 4, Sayfa No: 101, Hüküm No: 1. (Bu sayfadan itibaren arşiv ve ilgili defterin kısaltması kullanilacaktır.)
} 
değerlendirilmiştir. Geriye kalan 14 belge kadınların şikâyet edildiği belgelerdir. Aşağıdaki tabloda şikâyet hakkını kullanan kadınların toplam belge sayısına oranı görülmektedir.

Grafik 1: Toplam Belge Sayısının Kadınlara Oranı



Kaynak: 3 Numaralı Bosna Ahkâm Defteri (1-120)

Bu orana göre kadınların erkeklere nazaran şikâyet hakkını kullanımı noktasında oldukça sınırlı kaldıkları görülmektedir. Kadınların deneyim noktasında sınırlarını çizen pek çok ölçüt bulunduğunu belirten Göçek ve Baer (Göçek ve Baer, 2000:49) evlilik, ikamet ve toplum yapısı içerisindeki parametrelerin kadınların sınırlarını belirlediğini belirtmektedirler. Ancak kadı sicilleri üzerine yapılan çalışmalarda özellikle mülkiyet anlaşmazlığı konusunda kadınlar kayıtlarda düzenli bir biçimde görülmektedirler (Göçek ve Baer, 2000:55). Bu farkın temel sebebi, kadınların toplumsal yaşamda bulunma oranlarıyla orantılıdır. Gürhan'ın kadınlarla ilgili Diyarbakır ahkâm defteri kullanarak yaptığı çalışmada da kadınlar oransal olarak oldukça geri kalmış [\%4] bu durum kadınların önünde şikâyet hakkını kullanımı noktasında bir engel olmamasına rağmen pratikte durumun böyle olmadığını ortaya koymaktadır (Gürhan, 2017b:332).

\section{Kadınların Divân-ı Hümâyûn'a Başvuru Biçimleri veya Şikâyet İletim Şekli}

Belgeler incelediğinde ve aşağıdaki grafikte de görüldüğü üzere bizzat başvuru yapmanın şikâyetlerin Divân'da çözümlenmesi açısından önemini gösterir niteliktedir. Kendisi tarafından bizzat yapılan başvurularda belgede "gelüb" ifadesi yer alırken, yine kendisi gelip arzuhalle şikâyetini iletenlerin ise "rikâb-1 hümâyûnuma arz-1 hâl sunub5" veya "südde-i sa'âdetime 'arz-1

4 Saray Mahallâtında Oruç Pehlivan Mahallesinden Aişe nâm hâtûn gelüb... BOA, A.DVNS.AHK.BN.d.0003, Sayfa No:22, Hüküm No:2; Medîne-i Saray'da Aişe nâm hâtûn gelüb... BOA, A.DVNS.AHK.BN.d.0003, Sayfa No:25, Hüküm No:2.

${ }^{5}$ Fatma nâm hâtûn ile Halil ve Züleyha ve Zeyneb nâm yetimler rikâb-1 hümâyûnuma 'arz-1 hâl sunub... BOA, A.DVNS.AHK.BN.d.0003, Sayfa No: 54, Hüküm No:1. 
hâl idüb" şeklinde ifadelendirildiği görülmüştür. Arzuhal sunmak için İstanbul'a taşradan gelenler davasına en uygun, en etkili dilekçeyi hangi arzuhalcinin yazacağını tetkik etmeye çalışırdı. Arzuhalciler ise şikâyetin konusuna göre dönemin kural ve yasalarında dilekçenin yazılmasına mani bir durum olup olmadığına karar verirdi (Özgişi, 2014:56).

Grafik 2: Kadınların Şikâyet İletim Şekli

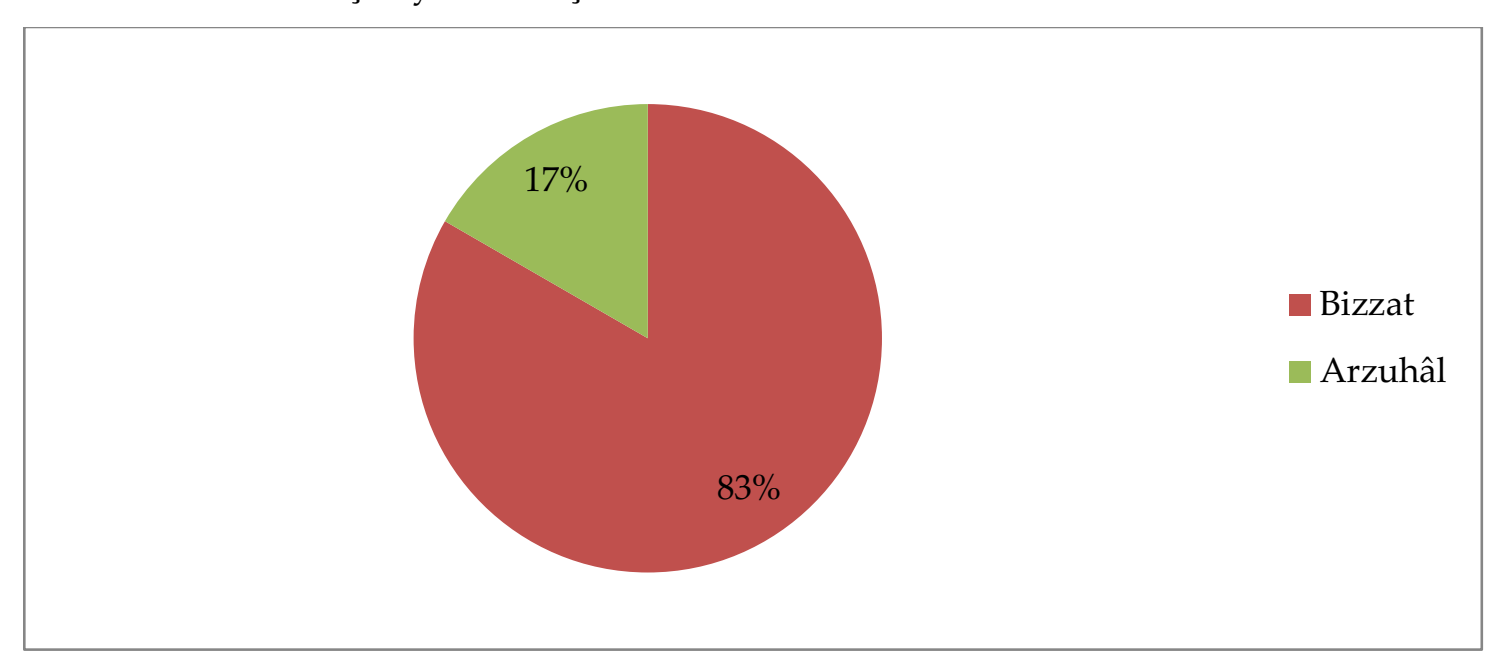

Kaynak: 3 Numaralı Bosna Ahkâm Defteri (1-120)

Şikâyet hakkının kullanımı noktasında her ne kadar kadınlar belgelerde az karşımıza çıksa da şikâyetlerini ilettiklerinde bizzat iletmeyi tercih ettiklerini ve bunun da oldukça yüksek bir orana karşıllk geldiğini söyleyebiliriz. 18 belge arasında kadınların sadece 3 hükümde Divân'a arzuhal sunduğu görülmüştür.

\section{İkamete Göre Başvuru}

Divân-1 Hümâyûn'un merkezi İstanbul'da ikâmet etmek şikâyeti iletmek ve sorunun çözümü noktasında oldukça önemli bir artıydı. Zira devletin geniş topraklara sahip olduğu düşünüldüğünde uzak bir eyâletten şikâyetin çözümü için İstanbul'a gelmek kolay değildi. Aşağıdaki grafik kadınların ikâmet ettikleri yerleri göstermektedir. 
Grafik 3: İkâmete Göre Başvuru

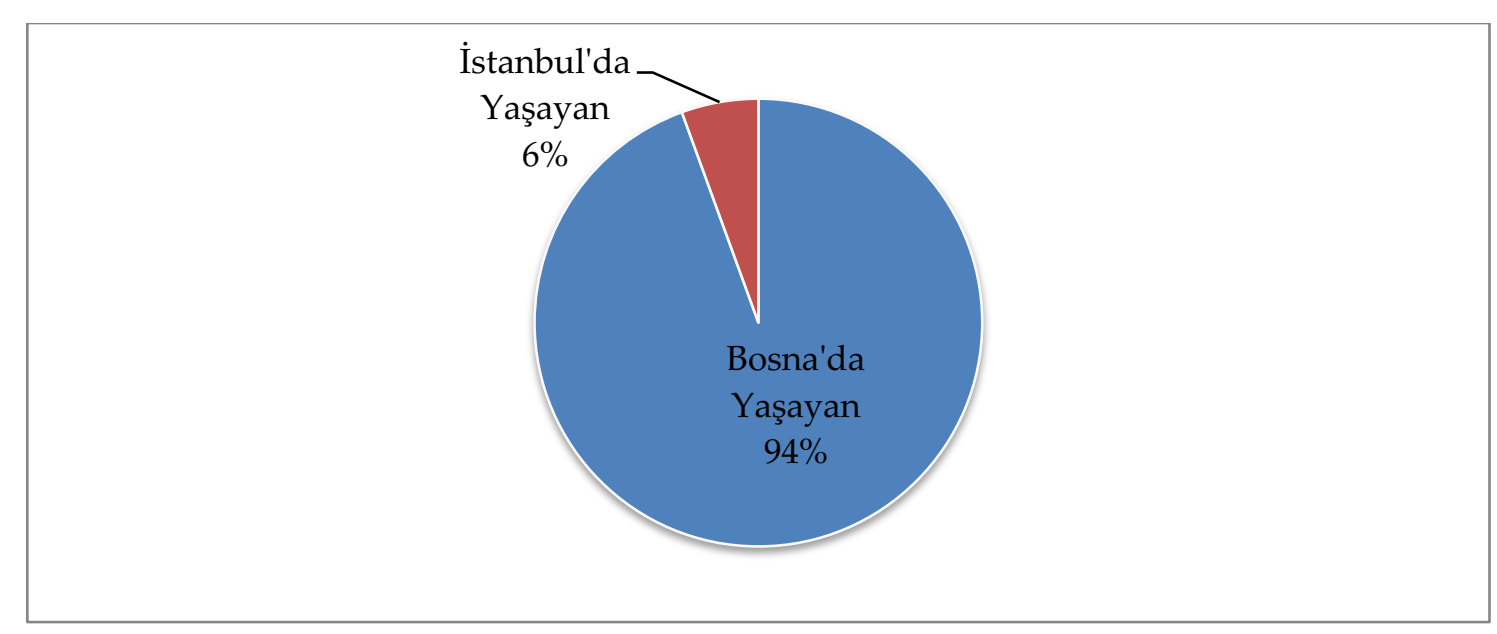

Kaynak: 3 Numaralı Bosna Ahkâm Defteri (1-120)

Divana gelerek başvuru yapanların ikamet ettikleri Bosna'nın İstanbul' da yaşayıp divana gelerek şikayetini aktaran kadınlara toplam başvuruya oranı \%6'dır. 18 şikâyetçi kadın arasından belgelere yansıyan İstanbul'da yaşayan kadın sayısının 1 olduğu ve onun da şikâyetini Divân'a ilettiğidir. Bu belgede miras malına müdahalede bulunan Hasan ve Hüseyin'i, Züleyha hatun şikâyet etmiştir. ${ }^{6}$ Züleyha hatun miras mallarını alması için Mustafa Efendi'yi vekil tayin etmiş, Divân'dan çıkan kararda ihtilafa yer verilmemesi, el konulmuş olan malların geri alınıp sahibine verilmesi ve konunun mahallinde şerle görülmesine dair karar verilmiştir.

\section{Kadınlar Tarafından Şikâyet Edilenlerin Cinsiyetleri}

Belgelerde kadınların en fazla şikâyet ettiği cinsiyet kimliğinin \%70 ile erkekler olduğu görülmüştür. 14 belgede kadınların erkeklerden şikâyetçi olduğu, 5 belgede ise kadınların kadınları şikâyet ettiği görülmüş̧ür. 2 belgede kadınlar hem erkek hem de kadınlardan şikâyetçi olmuşlardır. Bu iki belge tabloda iki tarafta da değerlendirilmiş olup içerikleri şu şekildedir. Rebîu'l-evvel ayı 179 senesinde Aişe hatun, Salih ve iki kız kardeşi ortak olarak konaklama yeri (menzil) işletmektedirler. Salih ve kız kardeşleri, Aişe hatunu kovup hissesine el koymuşlardır. Divân'a yapılan şikâyette adı geçenin hissesinin kendisine alınması ve konunun mahallinde şerle görülmesine dair karar verilmiştir.7 Aile içerisinde yaşanan bu şikâyette Aişe hatunun hakkının alınmasına yönelik Divân'dan karar çımış ve mahallinde sorunun çözülmesi istenmiştir. Sorunun mahallinde çözümünün istenmesi kadı mahkemesinin sorunun üstesinden gelebileceği ve olayın gerçekleştiği yer olarak incelemenin daha anlamlı olabileceğini düşünmüş olmalarından kaynaklanabilir.

Diğer örnekte ise $\mathrm{Zi}^{\prime} 1-\mathrm{ka}$ 'de ayı 180 senesinde Amine hatunun babası ve annesi vefat ettiğinden mirası kendisi ile kardeşleri Osman, Fatma ve Aişe'ye intikal etmiştir. Ancak kardeşi Osman diğer kardeşi Fatma ile anlaşıp miras malındaki hissesine zorla el koymuştur. Bu süreçte kardeşi Aişe'de payını alamadan vefat etmiş, onun payından alacağı hissesini ve kendi payını Osman'dan talep ettiğinde çeşitli bahanelerle vermekten kaçınmıştır. ${ }^{8}$ İslam kadına mirastan pay

\footnotetext{
${ }^{6}$ BOA, A.DVNS.AHK.BN.d.0003, Sayfa No: 36, Hüküm No: 2.

7 BOA, A.DVNS.AHK.BN.d.0003, Sayfa No: 25, Hüküm No: 2.

8 BOA, A.DVNS.AHK.BN.d.0003, Sayfa No: 86, Hüküm No: 3.
} 
alma hakkı tanımıştır. Bu hükümde sadece kardeşlerin mirasçı olduğunu kabul edersek kız yarım, erkek bir pay alacak şekilde taksim edilmesi gerekirdi. Her halükârda kız ve erkek kardeş birlikte bulundukları zaman pay oranı olarak belirtilen hakkı almaya sahiptiler (Efe, 2011:161). Osman daha fazla pay-hisse almak için kız kardeşinin hakkına tecavüz etmiş, kardeşi Amine'de hakkını Divân'da aramıştır. Divân'da görüşülen bu şikâyet sonucunda Amine'nin kanun ve deftere göre payının alınmasına ve mahallinde şerle görülmesine dair karar verilmiştir.

Bir belgede ise şikâyet edilen cinsiyet açık bir şekilde belirtilmemiştir. Safer ayı 1179 tarihinde Salih Efendi, tasarrufunda olan mülk menzilin yarısını şahitler huzurunda kızı Aişe hatuna devrettikten sonra vefat etmiştir. Varisleri ise babanın sana hibesini kabul etmiyoruz, mirasa katıp taksim ederiz diyerek ihtilaf yaratmışlardır. Aişe hatunda Divân'a gelerek babasının mirasçılarını şikâyet etmiş ve Divân'dan çıkan kararda varislerin men ve def edilmesi ve ihtilafın mahallinde şerle görülmesine karar verilmiştir. ${ }^{9}$ Belgede varislerin karşılığı olarak karşılaştığımız "ma'lûmu'l-esâmî kimesneler" ifadesi ile cinsiyet açık bir şekilde belirtilmemiştir.

Grafik 4: Kadınlar Tarafından Şikâyet Edilenlerin Cinsiyetleri

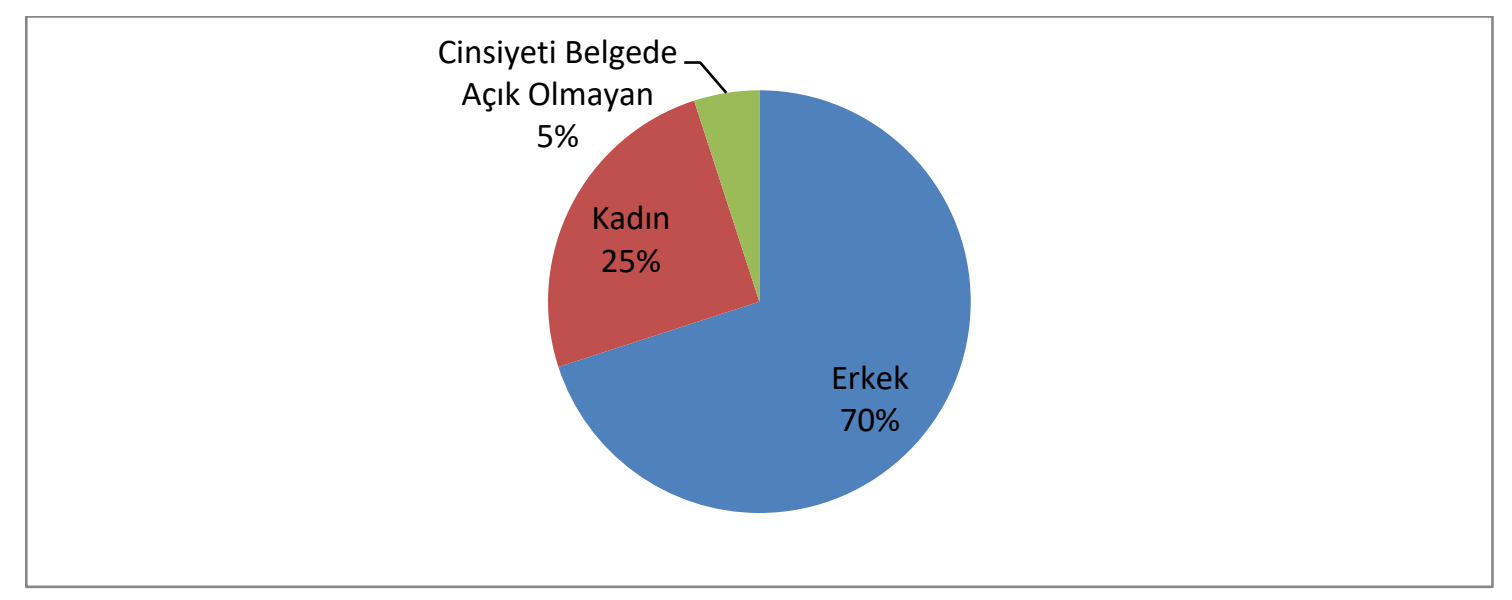

Kaynak: 3 Numaralı Bosna Ahkâm Defteri (1-120)

Aşağıdaki grafikte kadınların şikâyet ettiği erkeklerle yakınlık derecesi gösterilmektedir. Kadınlar tarafından şikâyet edilen erkeklerin \%65 gibi yüksek bir oranla kadınlarla bir bağ bulunmadığı tespit edilmiştir. Şikâyet edilen kişiler, bazı durumlarda şikâyet eden kişinin yaşının küçük olmasından ve dava kudretinde bulunamamasından yararlanmışlardır. Bu konuda örneğin; Rebî'u'l-âhir ayı 179 senesinde Nefise hatunun babası vefat ettiğinde mülk çiftlik ile çeşitli emlak, eşya ve yirmi kese akçe kendisine miras kalmıştır. Nefise hatun yaşı küçük ve uzakta bulunduğundan intikal eden bu malları Üsküplü İbrahim almıştır. Nefise hatun büyüyüp mallarını almak istediği sırada İbrahim vefat etmiş̧tir. Malları oğlu Alaybeyi Mustafa Ağa almış ve talep ettiğinde ise çeşitli bahanelerle erteleyip vermemiştir. ${ }^{10}$ Nefise hatunun sorunu muhtemelen çözümlenememiş olacak ki yaklaşık bir ay sonra Cemâziye'l-evvel ayı 179 senesinde Alaybeyi Mustafa'yı yine şikâyet etmiştir. Bu belgede dikkat çekici bir ifade Alaybeyi Mustafa'nın Nefise hatuna zamanı geçti davan dinlenilmeye değer bulunmaz diyerek çeşitli bahaneler üretmesi ve mallarını vermekten kaçınmasıdır. ${ }^{11}$

\footnotetext{
${ }^{9}$ BOA, A.DVNS.AHK.BN.d.0003, Sayfa No: 22, Hüküm No: 2.

${ }^{10}$ BOA, A.DVNS.AHK.BN.d.0003, Sayfa No: 31, Hüküm No: 1.

${ }^{11}$ BOA, A.DVNS.AHK.BN.d.0003, Sayfa No: 33, Hüküm No: 2.
} 
Grafik 5: Şikâyet Edilen Erkeklerin Kadınlarla Yakınlık Oranları

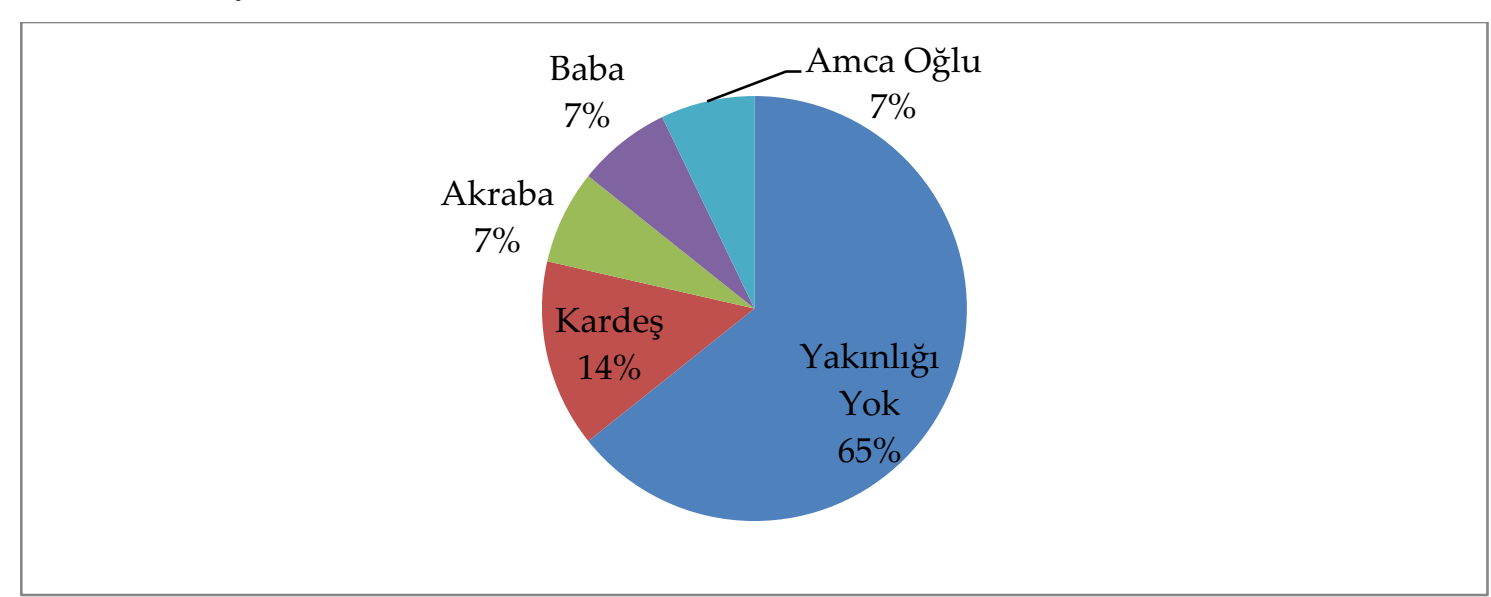

Kaynak: 3 Numaralı Bosna Ahkâm Defteri (1-120)

Diğer 2 belgede ise kadınların erkek kardeşlerini şikâyet ettiği görülmüştür. Daha önce içeriklerini belirttiğimiz $25 / 2$ ve $86 / 3$ numaralı hükümlerde kadınlar kardeşlerini şikâyet etmişlerdir. Grafiğe eşit düzeyde dağıldığını gördüğümüz ve belgelerde 1'er kez karşımıza çıkan baba, amcaoğlu ve akraba şikâyetinde ise Rebî' $u^{\prime}$ l-âhir ayı 1179 senesinde, Havva hatun babasını şikâyet etmiştir. Havva hatunun annesi Aişe'nin vefâtı ile kendisine ve kardeşlerine intikâl edecek miras mallarının tamamına babası el koymuştur. Meblağın ve diğer alacaklarının tahsil edilmesine dair karar verilmiştir. ${ }^{12}$ Miras malları taksim edilirken genellikle aile içi anlaşmazlıklar daha fazla olmakta ve birbirlerinin haklarına tecavüz kaçınılmaz olmaktadır.

Amcaoğlu ile ilgili şikâyette ise Yenipazar sakinlerinden Hanım hatuna babasından intikal eden bahçe ve konaklama yerine amcasının oğlu Ali zorla el koyduğundan şeyhülislamdan alınan fetvaya göre bahçe ve konaklama yerinin kendisine geri alınmasına dair karar verilmiştir.13 Şikâyetlerde dikkat çeken bir özellikte Şeyhü'l-islâm'dan alınan fetvalardır. Şikâyeti yapan kişi iddiasını kuvvetlendirmek amacıyla Divân'a fetva almış bir şekilde başvururdu. Böylelikle haklı olduğu noktasında bir nevi kendisine destek sağlamış olurdu (Gümrükçüoğlu, 2012:181).

Akraba ile ilgili şikâyette ise Rebî'u'l-âhir ayı 1179 senesinde, Hamiyet hatunun babası ve eşi vefat ettiğinden miras malları varisçileri arasında tahrir olunduktan sonra akrabalarından Kürkçü oğlu Kâdî Ali Efendi taksim için alacağı meblağı aldıktan sonra kalan ücret kendisinden talep edilmiştir. Ancak kadı a'yânlık iddi'asıyla vermemiştir. Divân'dan terekeden intikal eden paranın kendisinden tahsil edilmesine ve mahallinde şerle görülmesine dair karar verilmiştir. ${ }^{14}$ Hamiyet hatun akrabası olması yanında kadılık gibi önemli bir vazifede bulunan bir devlet görevlisini şikâyet etmiştir.

Kadınların şikâyetçi olduğu tüm belgeler dahil edildiğinde yine kadınların aile dışından kişileri daha fazla şikâyet ettiği görülmektedir. Genel olarak kadınların şikâyetçi oldukları nokta miras malına müdahale edilmesidir. Gürhan'ın (Gürhan, 2017b:337) Diyarbakır Eyâleti üzerine yaptığ çalışmada ise kadınların daha çok aile bireylerini veya akrabalarını şikâyet ettiği sonucuna ulaşılmıştır.

\footnotetext{
12 BOA, A.DVNS.AHK.BN.d.0003, Sayfa No: 28, Hüküm No: 2.

${ }^{13}$ BOA, A.DVNS.AHK.BN.d.0003, Sayfa No: 94, Hüküm No:2.

${ }^{14}$ BOA, A.DVNS.AHK.BN.d.0003, Sayfa No: 27, Hüküm No: 3.
} 
Grafik 6: Kadınların Şikâyet Ettiği Kişilerle Yakınlık Derecesi

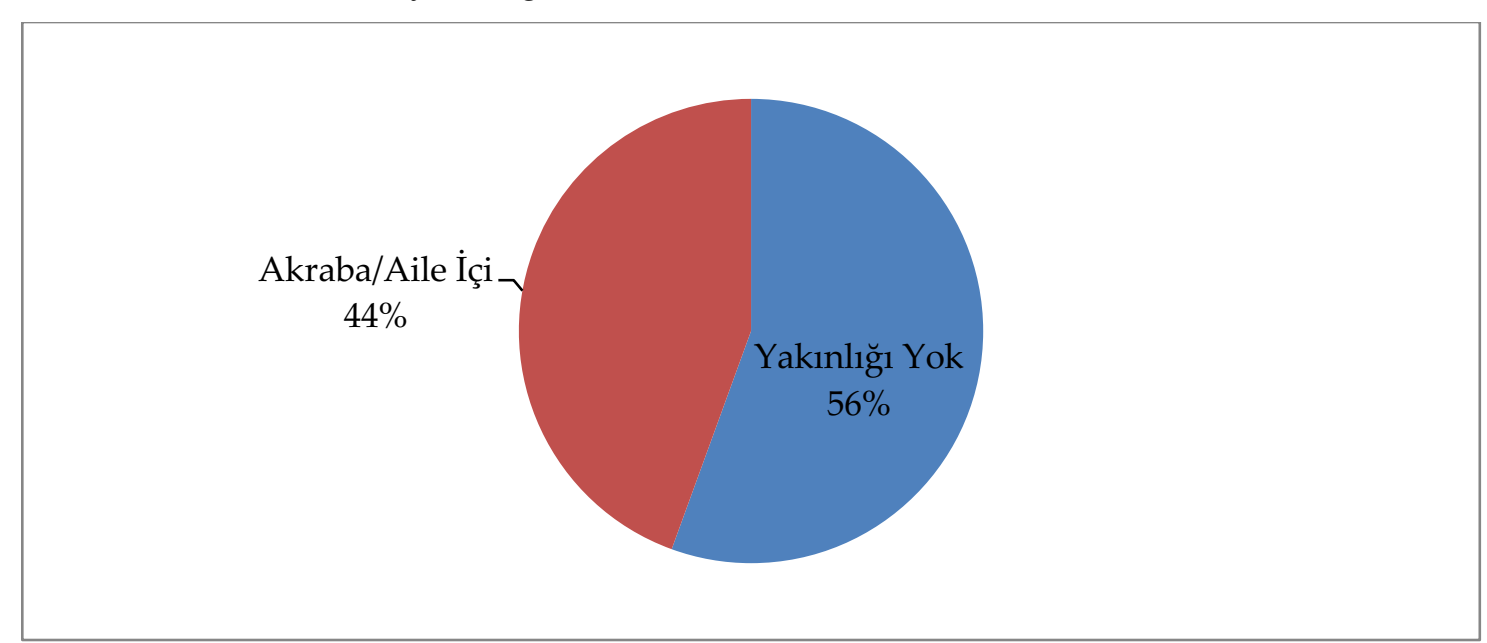

Kaynak: 3 Numaralı Bosna Ahkâm Defteri (1-120)

\section{ŞİKÂYET KONULARI}

Bosna'da kadınların şikâyet ettiği konular miras, arazi gasbı, mülk gasbı ve alacak-verecek konularıdır. Grafiğe yansıyan Bosna'da kadınların en çok miras paylarına yapılan müdahaleyi şikâyet ettikleri sonucudur. İslam miras hukuku, üzerinde tartışmaların yaşandığı bir alandır zira İslam şer'i intikâl kapsamında kadına mirastan pay hakkı tanımaktadır (Akyılmaz, 2007:472-473). İslam veraset yasaları kadınlara Yahudi hukuku ve 18. yüzyıl İngiliz hukukunda bile bulunmayan mirasta pay sahibi olma hakkı tanımıştır (Göçek ve Baer, 2000:57). İslamiyet'ten önce kadının kendisi pay edilirken, İslam kadına kişilik ve mirasçı sıfatını kazandırmıştır (Cin, 1979:4). İslam veraset hukukuna göre erkekler iktisadi gereksinimlere ihtiyaç duyduklarından erkek iki kadının hissesine eşit kabul edilmiştir. Mahkemeye gelen tüm tebaa içerisinde kadınlar erkeklerin yarısı kadar bir hisse almıştır (Göçek ve Baer, 2000:59-60). Tanzimat'tan sonra miras noktasında 1858 Arazi kanunnamesi kız çocuklarına erkeklerle eşit miras hakkı sağlamıştır (Işık, 2018:29).

Grafik 7: Kadınlar Tarafından Yapılan Şikâyetlerin Dağılımı

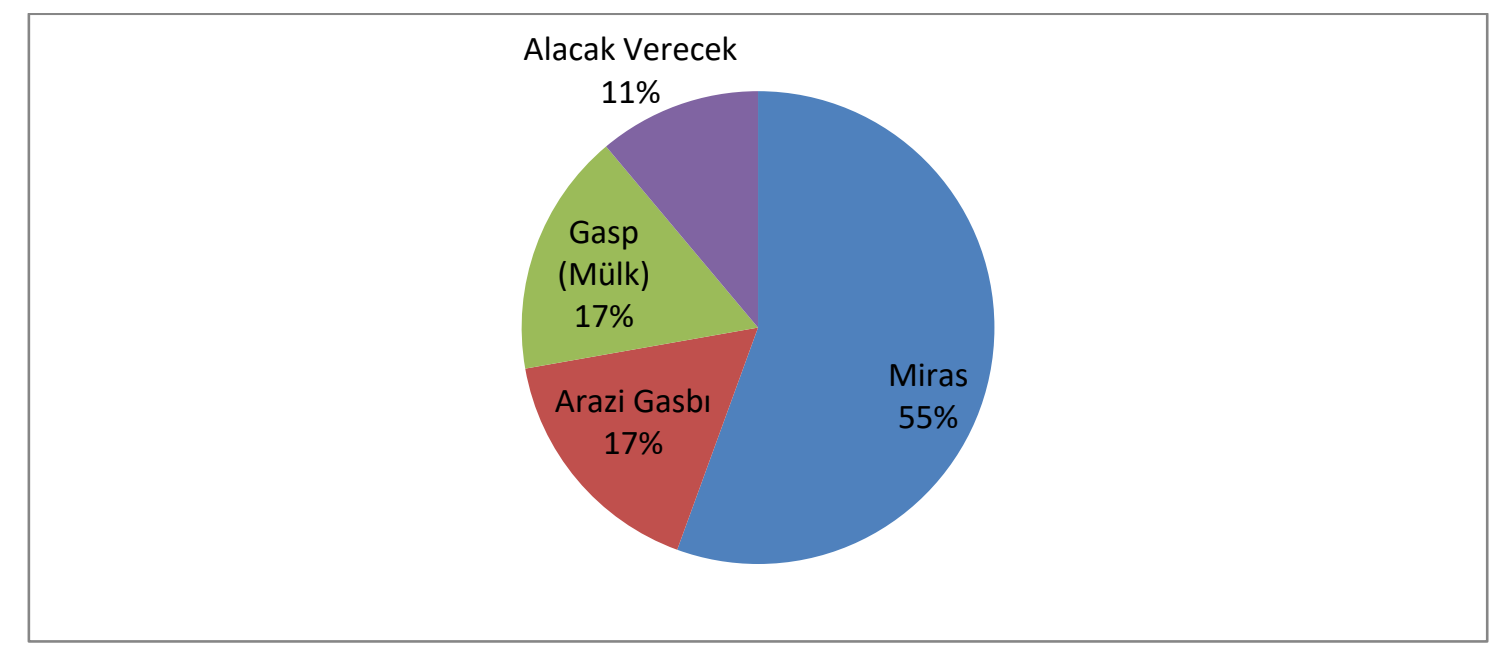

Kaynak: 3 Numaralı Bosna Ahkâm Defteri (1-120)

Kadınlar miras ve mehir yoluyla ellerinde bulunan menkul ve gayr-ı menkulleri satış veya ticari faaliyet kapsamında kiraya vererek çeşitli işlere dahil olmuşlardır (Koyuncu Kaya, 2018: 299). Bu 
durum bize mirasın kadınlar açısından öneminin bir kat daha fazla olduğunu düşündürtmektedir. Çalışmamızda miras ile ilgili yaşanan ihtilaflarda mirasçı olmayan kişilerin miras mallarına el koyarak gasp ettikleri veya aile içinden alacağı pay ile yetinmeyen mirasçıların neden olduğu şikâyetlerle karşılaşılmaktadır. Örneğin, Rebî‘u'l-âhir ayı 1181 senesinde Memlehateyn kasabasından Fatma ve Aişe'nin babaları Hüseyin vefat etmiştir. Vefatı sonrası kalan mirasına kendileri o sıralarda yaşları küçük bulunduğundan İsmail zorla el koymuştur. Büyüdüklerinde mallarını talep ettiklerinde ise vakti geçti diyerek çeşitli bahaneler üretmiştir. Şeyhü'l-islâmdan fetva alarak Divân'a başvuran bu kadınlara cevap olarak konunun fetvaya göre mahallinde şerle görülmesi ve haklarının alınması olmuştur. ${ }^{15}$ Yine daha önce belirttiğimiz Safer ayı 1181 senesinde Yenibazar sakinlerinden Hanım hatuna babasından intikâl eden bahçe ve konaklama yerine amcasının oğlu Ali zorla el koyduğundan Şeyhü'l-islâmdan alınan fetvaya göre bahçe ve konaklama yeri kendisine geri alınıp mahallinde ihtilafın şerle görülmesine karar verilmiştir. ${ }^{16}$

Miras'tan sonra kadınların en fazla şikâyet ettiği konular eşit oranda grafiğe yansıyan arazi gasbı ve mülk gasbıdır. Arazi gasbına şu hükümler örnek verilebilir. Zakire hatunun tasarrufunda olan tarla ve çayırına Kozarca kalesi sakinlerinden Başo ve kardeşleri müdahil olmuştur. Görülen davada Başo ve kardeşlerinin haksız olduğu anlaşılmış olup, tekrar toprak ve çayırın Zakire hatuna alınmasına karar verilmiştir. ${ }^{17}$ Zakire hatun tapulu ve temessüklü olan topraklarının vergisini toprak sahibine öderken zorba takımından olan bu kişiler müdahil olmuşlardır. Zakire'nin hakkının alınmasına yönelik karar verilmişken adı geçenler kuvvetleri sebebiyle müdahalelerine devam etmişlerdir. Konunun Bosna valisi tarafından çözümlenmesine yönelik Divân' da karar verilmiş ve hakkı olan yerlerin alınmasına çalışılmıştır. Bir bölgenin gerek mali gerekse de askeri olarak güçlü kimseleri ihtilaf yarattıklarında bu davranışlarından vazgeçmelerine yönelik tembihte bulunulurdu. Genellikle belgelerde görüldüğü kadarıyla bu faaliyet pek işe yaramaz ve şikâyet konusu davranış devam ederdi. Hükümde geçen Başo ve kardeşlerine de tembih de bulunulmuş ancak işe yaramamıştır.

Bir diğer örnek ise Rebî‘u'l-evvel ayı 1181 senesinde Mehmed ile kardeşi Ahmed ortak olarak arazi tasarruf etmektedir. Ahmed uzak bir yere gidip kendisinden on senedir ne bir haber ne de mektup alınamadığından hakkı tapuya geçmiştir. Mehmed'de kardeşinin hakkını sahibinden tapu resmi ödeyerek almıştır. Mehmed haklarını eşi Kamile hatuna bedeli karşılığında devretmiştir. Mehmed vefat edince kız kardeşi Zeynep ve eşi Arslan kardeşinin bu arazileri devretmediğini söyleyip ihtilaf yaratmışlardır. İki kez yapılan murafaalarında iddialarının asılsız olduğu anlaşıldığından adı geçenlerin men ve def edilmesine ve kanun üzere iş yapılmasına karar verilmiştir. ${ }^{18}$ Bu hükümde dikkat çeken noktalardan biri iki kez yüzleştirme yapılmasıdır. Zeynep, muhtemelen iddiasında ısrarcı olmaya devam ettiği için ikinci kez yüzleştirme yapılmıştır. Ancak buna rağmen müdahalesine devam etmiş sorunun çözümü için Zeynep'in men ve def edilmesine karar verilmiştir.

Arazi gasbı ile eşit düzeyde grafiğe yansıyan mülk gasbına şu hükümler örnek verilebilir. Zi'lka'de ayı 179 senesinde Kezban hatun tasarrufunda olan bahçenin bir kısmını Sakaleli oğlu Süleyman'a satmıştır. Satışın ardından Süleyman bu yerden haksız kazanç elde etmiş ve Kezban'a ödeyeceği meblağı ödememiştir. Kezban, bahçeyi geri talep ettiğinde Süleyman çeşitli

\footnotetext{
${ }^{15}$ BOA, A.DVNS.AHK.BN.d.0003, Sayfa No: 106, Hüküm No: 2.

${ }^{16}$ BOA, A.DVNS.AHK.BN.d.0003, Sayfa No: 94, Hüküm No: 2.

17 BOA, A.DVNS.AHK.BN.d.0003, Sayfa No: 37, Hüküm No: 3.

${ }^{18}$ BOA, A.DVNS.AHK.BN.d.0003, Sayfa No: 99, Hüküm No: 4.
} 
bahaneler öne sürerek bahçeyi vermekten kaçınmıştır. Bu konuda Divân'dan hakkının geri alınmasına ve ihtilafın mahallinde şerle görülmesine karar verilmiştir. ${ }^{19}$

Mülk gasbı ile ilgili bir diğer hükümde Arife ve Naile adlı hatunlar ile kardeşleri İbrahim'e babaları İbrahim vefat edince çiftlik ve bahçesi miras kalmıştır. İbrahim payına düşeni zorba takımından Beşir ve Osman'a satmıştır. Beşir ve Osman satın aldıkları hisse ile yetinmeyip Arife ve Naile'nin hissesine de el koymuşlardır. Arife ve kardeşinin Divân'a intikâl eden şikâyetlerinde el koydukları çiftlik ve bahçenin kendilerine geri alınmasına karar verilmiştir. ${ }^{20}$

Alacak-verecek ihtilafına örnek olarak ise Zi'l-ka'de ayı 179 senesinde Fatma, Halil, Züleyha ve Zeynep'in babalarından ve Fatma'nın evliliğinden intikâl eden üç bin guruş alacakları Mehmed Şehri'de bulunmaktadır. Talep edildiğinde çeşitli bahanelerle erteleyip Bosna'ya firar ettiğinden çavuş marifetiyle İstanbul'a getirilmesi ve hasımları ile yüzleştirilmesine dair Divân'dan karar çıkmıştır. ${ }^{21}$ Çavuş marifetiyle ihtilafın çözülmesi noktası ise şikâyet davalarında güç kullanmayı gerektiren bir durum olduğu anlamına gelir. Zira mübaşir veya çavuş tayini taşrada devletin hakim gücünü sağlayarak alınan kararların uygulanmasını sağlamıştır (Tuğluca, 2016:83-84).

\section{Kadınlardan Şikâyet Edilen Konular}

Kadınlar şikâyet eden olabildikleri gibi şikâyet edildikleri de olmuştur. 9 belgede kadınların şikâyet edildikleri ayrıca 5 belgede şikâyet eden kişinin kadın şikâyet edilenin de kadın olduğu belirlenmiştir. Bu 5 belge her iki tarafta da değerlendirilmiştir. Kadınlardan şikâyet edilen toplam belge sayısı $14^{\prime}$ 'tür.

Grafik 8: Kadınlardan Şikâyet Edilen Konular

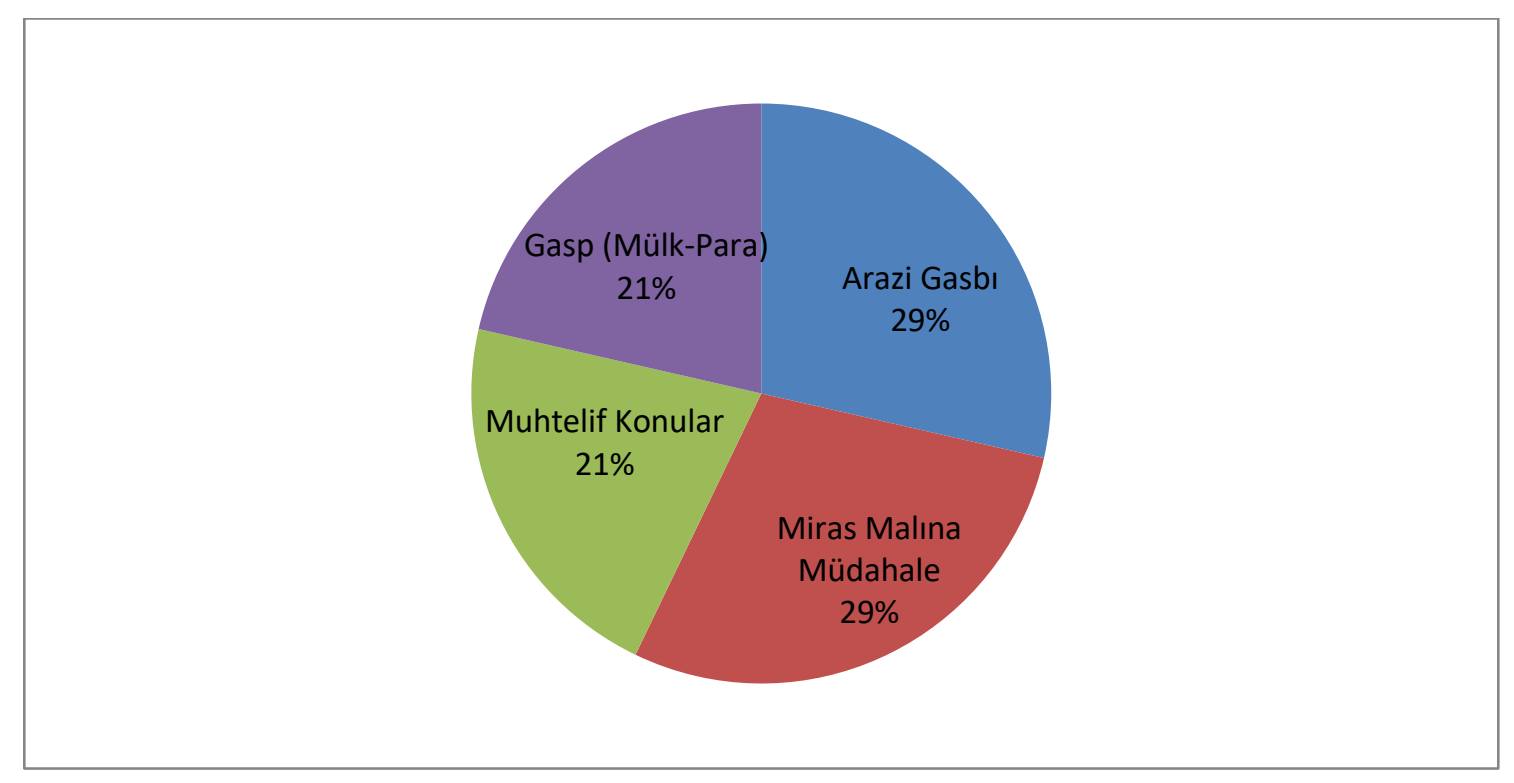

Kaynak: 3 Numaralı Bosna Ahkâm Defteri (1-120)

\footnotetext{
${ }^{19}$ BOA, A.DVNS.AHK.BN.d.0003, Sayfa No: 54, Hüküm No: 2.

${ }^{20}$ BOA, A.DVNS.AHK.BN.d.0003, Sayfa No:83, Hüküm No: 2.

${ }^{21}$ BOA, A.DVNS.AHK.BN.d.0003, Sayfa No:54, Hüküm No: 1.
} 
Kadınlardan en çok şikâyet edilen iki konu grafiğe de eşit oranda yansıdı̆̆ı üzere arazi gasbı ve miras malına müdahaledir. Arazi gasbına örnek olarak şu hükümler verilebilir. Glamoç nahiyesi sakinlerinden Gülhane hatunun babası vefat ettikten sonra oğlu kalmadığından tasarrufunda olan araziler kanuna göre tapuya geçtikten sonra kendisi tapu resmî vererek toprakları işlemek üzere almıştır. Amcası vefat ettikten sonra kızı Fatma arazilerin yarısı senden önce abimdeydi yarısını ben alacağım ve bunun dışında babam katledildiğinden babamın diyeti karşılığı alacağım para da senin babanda kaldı diyerek Bosna Divânına şikâyette bulunmuştur. Yüzleştirildiklerinde iddiasını kanıtlayamadığı ve müdahalesinde ise ssrarcı olduğundan men edilmesine ve şikâyetin mahallinde şerle görülmesine karar verilmiştir. Burada arazi ihtilafı dışında Bosna divanına şikâyet yapıldığı görülmektedir. Yüzleştirme yapılarak sorun çözülmüş ancak Fatma uzun bir süre sonra tekrar Gülhane hatuna rahatsızlık vermeye başlayınca konu Divân-1 Hümâyûn'a intikâl etmiş ve men edilmesi kararı çıkmıştır.22 Bir diğer örnek ise Muharrem ayı 1180 senesinde Misırlızade Cafer' in ve ortağının tasarrufunda olan arazide ortağı vefat ettikten sonra tapu sahiplerinden kimsesi olmadığından kanuna göre hakkı tapuya ve ortağı olduğu içinde kendisine geçmiştir. Taşlıca sakinlerinden Cafer Bey'in eşi bu yeri zorla alıp bu dava ettiğinde ise eşinin gücünden yararlanarak araziyi vermemiştir. Divân' dan çıkan kararda mağduriyetinin giderilmesi ve arazinin kendisine alınmasına karar verilmiştir. ${ }^{23}$ Arazi gasbı ile ilgili son örneğimiz ise Rebî'u'l-evvel ayı 1181 senesinde İsmail kendi rızası ile Hayrizade Mehemmed Said efendiden tasarrufunda olan arazileri almıştır. Ali efendinin eşi hile ile uydurulmuş senet ibraz ederek arazinin yarısının kendisine eşinden intikal ettiğini belirtip araziye zorla el koymuştur. Divân'dan çıkan kararda kadının kanuna aykırı müdahalesinden men ve def edilmesine ve arazinin geri alınmasına karar verilmiştir. ${ }^{24} \mathrm{Bu}$ belgelerde dikkat çeken noktalar kadınların müdahalede bulunurken bazen eşlerinin gücünden yararlandığı bazen de daha da ileri giderek belgede sahtecilik yaptıklarıdır.

Miras malına müdahale ile ilgili olarak, Cemâziye'l-âhir ayı 1180 senesinde Saray Bosna'da Çoban Hasan mahallesindeki konak yerini önceden Mehmed Paşa ibn-i Ferhad Bey satın alıp aradan yirmi sekiz sene geçtikten sonra vefat etmiştir. Mirası varislerine intikal ettiğinde ahaliden Vilahbike oğlu el-Hacc İbrahim'in eski eşi Zeliha konak yerinin Mehmed Paşa'dan önce kendisinin olduğunu beyan eden ruka ${ }^{25}$ sunmuştur. Yapılan incelemelerde adı geçenin iddiasının asılsız olduğu anlaşılmış bu konuda yalanlarına itibar edilmemesi ve konunun mahallinde şerle görülmesine karar verilmiştir. ${ }^{26}$ Miras ile ilgili bir diğer hükümde Mehmed Said'in babası Derviş Ali vefat etmiştir. Mirası bununla, annesi ve kız kardeşine intikal etmiştir. Ancak kendisinin uzak bir yere gitmesini fırsat bilen annesi Nizame kendisinin payı olan mülklere el koymuştur. Divân'a yapılmış olan bu şikâyette konunun şerle görülüp hakkın yerine getirilmesine ve mahallinde şerle görülmesine karar verilmiştir. ${ }^{27}$ Miras malına müdahaleyi ya konu ile alakası olmayan ahaliden bazı kişiler yapmış ya da aile içinde alacağı pay ile yetinmeyen bazıları müdahalede bulunarak diğer varisçilerin haklarına el koymuşlardır.

Muhtelif konular başlığını verdiğimiz şikâyetlerde konusuna göre farklı şikâyetler olduğu için bu başlık altında toplandı. Bu konuda ilk örnek haksız talebinde ısrarcı olan Kerime ile ilgilidir. Safer ayı 1181 senesinde Hacı Mehmed'in kızı Kerime babasından kendine miras kalan malları ve parayı tahsil için Ahmed isimli kişiyi vekil tayin etmiştir. Ahmet' de bu malları ve parayı alıp

\footnotetext{
22 BOA, A.DVNS.AHK.BN.d.0003, Sayfa No:41, Hüküm No: 1.

${ }^{23}$ BOA, A.DVNS.AHK.BN.d.0003, Sayfa No: 60, Hüküm No: 4.

${ }^{24}$ BOA, A.DVNS.AHK.BN.d.0003, Sayfa No: 100, Hüküm No: 4.

${ }^{25}$ Dilekçe, arzuhal.

${ }^{26}$ BOA, A.DVNS.AHK.BN.d.0003, Sayfa No: 72, Hüküm No: 2.

27 BOA, A.DVNS.AHK.BN.d.0003, Sayfa No: 120, Hüküm No: 3.
} 
Kerime'ye teslim etmesine rağmen, Kerime benim babamın mirasından alacağım kaldı diyerek Ahmed'i rahatsız etmiştir. Görülen davasında iddiasının asılsız olduğu anlaşılmasına rağmen, Kerime iddiasında 1srarcı olduğundan men ve def edilmesine ve mahallinde şerle görülmesine dair karar verilmiştir.28 Kerime hatunun rahatsız ettiği Ahmet kadı olup, bir kadının haksız olduğuna dair karar çıkmasına rağmen kadıyı rahatsız etmeye devam etmesi kadınların bu dönemde sınırlarında ötesine geçtiğini göstermektedir.

Bir diğer hüküm Bosna valisi Mehmed Paşa'nın eşi Hace Zeynep'in yaptığı satış işleminin feshedilmesine yönelik hükümdür. Bosna Valisi Mehmed Paşa'nın eşi Hace Zeynep tasarrufunda olan yerleri satışa çıkardığında o köyde bulunanlar almaya talip iken bunlara vermeyip kanuna aykırı olarak dışarıdan zaim Mustafa ve Mir Alim adlı kişilere sattığından satış işleminin feshedilmesine dair karar Divân' dan çıkmıştır. Divân-ı Hümâyûn kaleminden bu konu ile alakalı kanun sorulduğunda satış işlemi üzerinden bir sene geçmemiş ise satış işleminin feshedilmesine, eğer bir sene geçmiş ise ahalinin iddialarının kanuna aykırı olduğu yönünde der-kenâr yazılmıştır. Hace Zeynep'in yaptığı işlemin üzerinden bir yıl geçmemiş olacak ki işlemi iptal ediliştir.

Bu başlık ile ilgili son hüküm ise mehir ile alakalıdır. Asiye hatun dayısını vekil yaparak Mehmed ile evlenmek için belli bir miktar mehir almıştır. Aralarındaki akd geçerli iken evlendikten sonra pişman olduğunu belirtip akdi fesih etmek istemiştir. Mehmed, şeyhülislamdan şikâyeti ile alakalı bir fetva almıştır. Alınan fetvaya göre Divân'dan çıkan kararda Asiye'nin tekrar Mehmed ile evlenmesine karar verilmiştir. ${ }^{29}$ Mehr, kadının toplumdaki konumunu yansıtacak en iyi statüyü belirlemede kullanılan bir araçtır (İmber, 2000:95). Mehrin tamamı nikah sırasında veya daha sonra ödenebilmektedir. Genel kabul gören uygulama ise bir kısmının peşin, bir kısmının daha sonra ödenmesine yöneliktir (Aydın, 2003:390). Geçerli bir nikah akdi mehri gerektirir bu hükümde de Mehmed, evliliğin gereği olan mehri Asiye'ye ödemiştir. Asiye, mehrin gereği olan akçeyi aldıktan sonra pişman olduğunu söyleyerek bir nevi aldığı akçeye el koymaya kalkışmıştır. Mehmed, Divân-ı Hümâyûn'a şikâyetini iletmiş, Asiye'nin kendisi ile evliliğinin devamina karar verilmiştir.

Muhtelif konularla eşit orana sahip gasp (mülk-para) ile ilgili ise şu hükümler örnek verilebilir. Rebîu'l-evvel ayı 179 senesinde Aişe hatun, Salih ve iki kız kardeşi ortak olarak konaklama yeri (menzil) işletmektedirler. Salih ve kız kardeşleri, Aişe hatunu kovup hissesine el koymuşlardır. Divân'a yapılan şikâyette adı geçenin hissesinin kendisine alınması ve konunun mahallinde şerle görülmesine dair karar çıkmıştır. ${ }^{30}$ Para gasbı konusunda ise aynı hükmün iki kez yer aldığı görülmüştür. Bu hükümde, Zeynep'e yaşı küçükken babasının vefatı ile kendine intikal eden mallar ve para için Hasan adlı kişi vasi tayin edilmiştir. Hasan, Zeynep büyüdügünde mallarını ve parasını teslim etmiştir. Zeynep, niyeti kötü olan kişilerin tahrikiyle babasından intikâl eden paralar için, faizde kullansan daha fazla gelir elde ederdin diyerek fuzuli olarak Hasan'ın bin yetmiş guruşunu gasp etmiştir. Konunun mahallinde şerle görülmesi ve zorla alınan meblağın geri alınmasına karar verilmiştir. ${ }^{31}$ Görüldüŭgü üzere kadınlar, kendilerine gelir getirecek olan mülk ve parasal kıymete haiz şeyleri oldukça önemsemekte ve hakları olmamasına rağmen zorla da olsa almaya çalışmaktadırlar.

\footnotetext{
${ }^{28}$ BOA, A.DVNS.AHK.BN.d.0003, Sayfa No: 91, Hüküm No: 4.

${ }^{29}$ BOA, A.DVNS.AHK.BN.d.0003, Sayfa No: 48, Hüküm No: 2.

${ }^{30}$ BOA, A.DVNS.AHK.BN.d.0003, Sayfa No: 25, Hüküm No: 2.

${ }^{31}$ BOA, A.DVNS.AHK.BN.d.0003, Sayfa No: 5, Hüküm No: 1, Sayfa No: 6, Hüküm No: 3.
} 


\section{Sorunun Çözümünde Merkezin Muhatap Aldığı Yöneticiler}

İncelediğimiz belgelerde şikâyet Divân'a ulaştıktan sonra sorunun çözümü için kendisine en fazla hitap edilen görevli kadı olmuştur. Belgelerde \%53 oranında kadı vali ile birlikte muhatap kabul edilmiştir. Aşağıdaki grafik hükümlerin tek bir kişiye gönderildiği varsayılarak oluşturulmuştur. Örneğin Bosna valisine ve Saray mollasına hüküm ki şeklinde yazılan bir hükümde, valiye gönderilen bir, mollaya gönderilen bir şeklinde kabul edilmiş ve aşağıdaki grafik oluşturulmuştur. Diğer grafik ise hükümlerin birlikte gönderildiği yöneticilerin oranını temsil etmektedir.

Grafik 9: Merkezin Muhatap Aldığg Yöneticiler

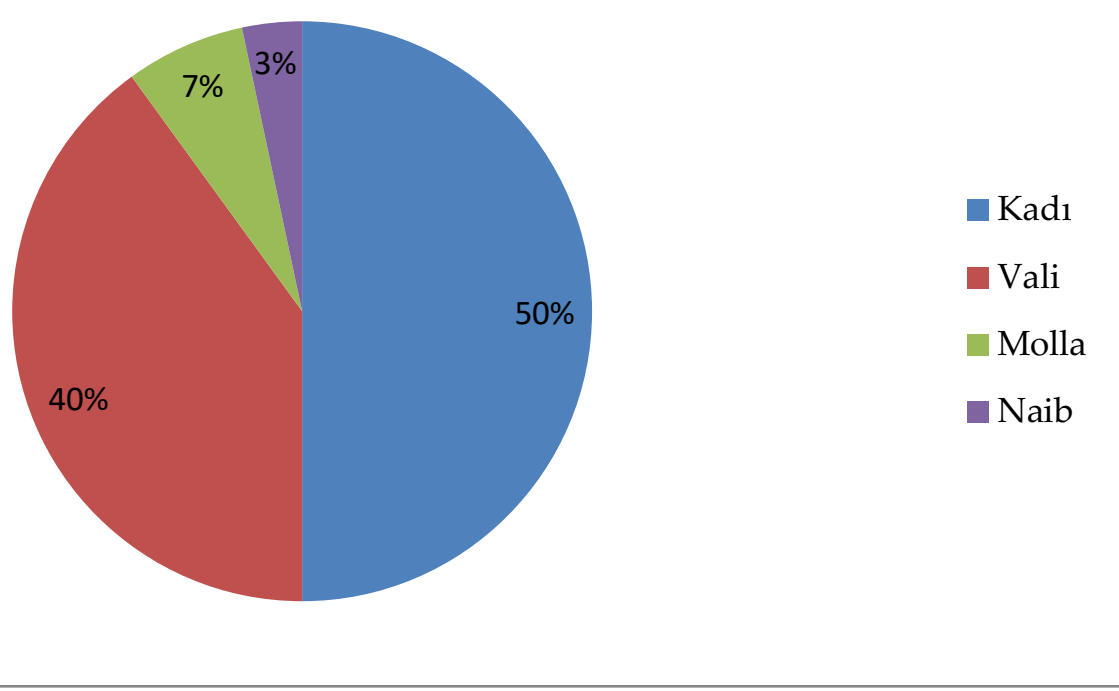

Kaynak: 3 Numaralı Bosna Ahkâm Defteri (1-120)

Grafik 10: Hükümlerin Birlikte Gönderildiği Yöneticiler

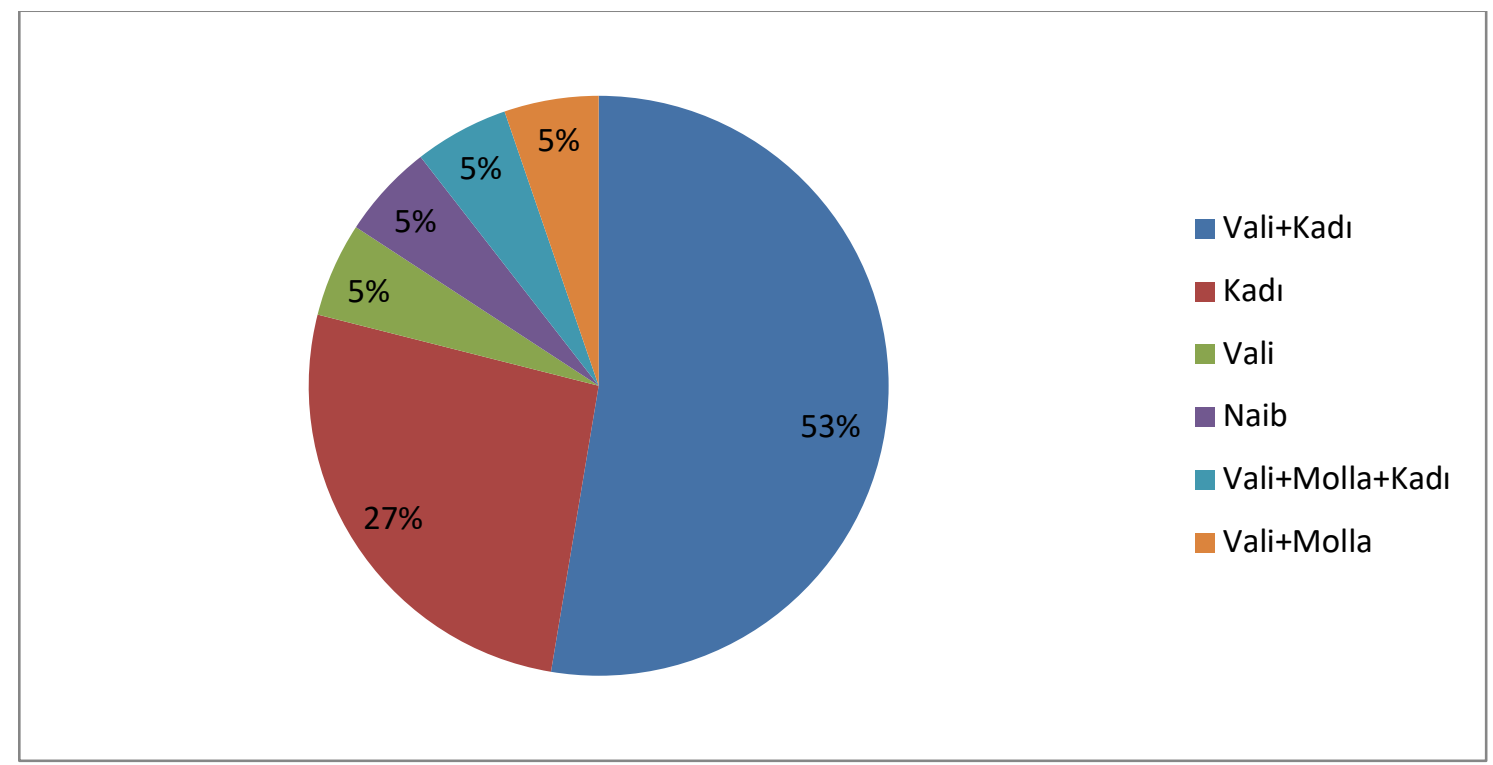

Kaynak: 3 Numaralı Bosna Ahkâm Defteri (1-120) 
Divân-1 Hümâyûn'dan sorununun çözümü noktasında hakkını alan bir şikâyetçi, bulunduğu yerin kadısına gelerek hükmü kadı sicil defterine kaydettirir ve bu andan sonra artık hükmün uygulanmasından kadı ve diğer ehl-i örf sorumlu olurdu. Kadılar, ehl-i örfünde desteğiyle şikâyet hükmünü uygulayarak şikâyet mekanizmasının son kısmını teşkil etmiş olurdu (Tuğluca, 2016:84-85). 5 hükmün doğrudan kadıya ${ }^{32}$, diğer muhtelif görevlilerinde ${ }^{33} 1^{\prime}$ er kez şikâyetlerin çözümü noktasında görev aldığı görülmüş̧ür.

\section{Divân'ın Sorunları Çözme Yöntemi}

Divân-1 Hümâyûn kendisine intikâl eden şikâyetleri çözüm noktasında birkaç yöntem uygulamaktadır. Bunlar mahalline havâle etme, kendisinin sonuca bağlaması ve çavuş marifetiyle şikâyet edilen kişinin divana getirilmesidir. Divân bu yöntemleri belirlerken; konunun içeriğine, kişilerin toplumsal mevkilerine ve Divân'ın merkezde toplanamamış olmasına dikkat etmektedir (Tuğluca, 2016:36).

Grafik 11: Divân'ın Sorunları Çözme Yöntemleri

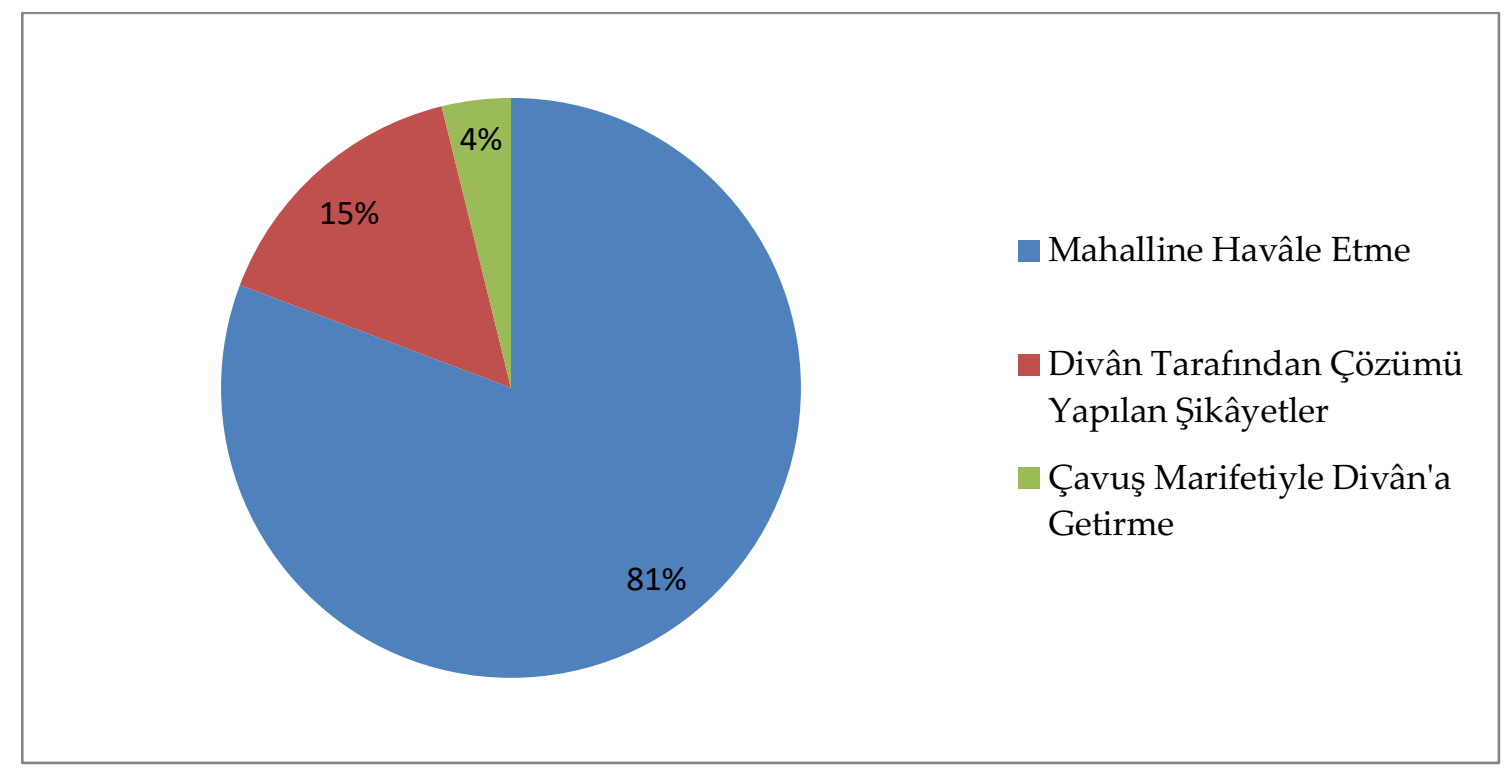

Kaynak: 3 Numaralı Bosna Ahkâm Defteri (1-120)

Divân çoğu zaman sorunu kendisi çözmek yerine mahalline göndermeyi tercih etmektedir. ${ }^{34}$ Zira mahalli birimlerde yargılama işini yapan kadılar bulunmakta ve işleyişin devamı için bu yöntem

${ }^{32}$ Doğrudan Kadı'ya gönderilen hükümler şunlardır. BOA, A.DVNS.AHK.BN.d.0003, Sayfa No: 37, Hüküm No: 3, Sayfa No: 41, Hüküm No: 1, Sayfa No: 99, Hüküm No: 4, Sayfa No: 101, Hüküm No: 1, Sayfa No: 106, Hüküm No: 2.

${ }^{33}$ Sadece Vali'ye gönderilen, BOA, A.DVNS.AHK.BN.d.0003, Sayfa No: 54, Hüküm No: 1; Sadece Naib'e gönderilen, BOA, A.DVNS.AHK.BN.d.0003, Sayfa No: 54, Hüküm No: 2; Vali ve Molla'ya gönderilen BOA, A.DVNS.AHK.BN.d.0003, Sayfa No: 25, Hüküm No: 2; Hem Vali hem Kadı hem de Molla'ya gönderilen BOA, A.DVNS.AHK.BN.d.0003, Sayfa No: 27, Hüküm No: 3.

34 "hükm-i hümâyûnum ricâ itmeğin mahallinde şer'ile görülmek içün yazılmışdır.", BOA, A.DVNS.AHK.BN.d.0003, Sayfa No: 25, Hüküm No: 2; “icrâ-yı şer” ve ihkâk-ı hakk olunmak 
tercih edilmektedir. Şikâyet eden kişiler kazasına gönderilirken yanlarında sorunlarını çözümleyici bazı belgelerde bulunurdu. Örneğin, "bu bâbda şeyhü’l-islâmdan fetvâ-yı şerîfesi olduğun bildürüb" ifadesi ile "fetvâ-yı münîfe mûcebince marîfet-i şer'le görülüb" ifadesi kadıya şikâyeti tekrar kanun veya fetvaya göre çözmesini söylemekteydi. ${ }^{35}$ Divân'ın sorunu kendisinin çözümüne örnek olarak“....kendüye alıvirilüb mezbûreyi hilâf-1 kânûn táallül ve terdîd itdirilmemek bâbında emr-i şerîfim ricâ itmeğin kânûn üzere 'amel olunmak içün yazılmışdır. ${ }^{36 "}$ ifadesi verilebilir. Çavuş marifetiyle divana getirme yöntemi fazla uygulanan bir yöntem değildir. Özellikle taşrada sorunun çözümü mümkün olmayan şikâyetlerde divan tarafından mübaşir/çavuş gönderilmiştir. Bir hükümde yetimlere borcu olan ve ödemeyi geciktiren, talep edildiğinde ise çeşitli yerlere firar eden Mehmed Şehri'nin çavuş marifetiyle divanda hazır bulundurulmasına karar verilmiştir. ${ }^{37}$

\section{SONUÇ}

Adalet, iktidarını devam ettirmek isteyen her otorite tarafından oldukça önemsenen bir olgudur. Osmanlı Devleti'de gerek kendisinden önceki Türk-İslam devletlerinden gerekse de Yakındoğu devlet geleneğinden almış olduğu mirası harmanlamış ve yönetim anlayışını şekillendirmiştir. Bu yönetim anlayışında şikâyet hakkı hiçbir cinsiyet ayrımı yapılmaksızın her bireye tanınmıştır. Kadı sicilleri üzerine yapılan çalışmalarda kadınlar ile erkekler arasında şikâyet hakkının kullanımı noktasında fark olmadığı belirtilmiştir. Ancak ahkâm defteri kullanarak yapmış olduğumuz bu çalışmada kadınlar erkeklere nazaran oldukça geri planda kalmıştır. Bu durum Bosna gibi nispeten uzak bir eyâletten gelmenin zor olduğu düşünüldügünde kadınlar açısından sonucun neden düşük çıktığı anlaşılabilmektedir. Şikâyet iletimi açısından İstanbul'da ikâmet etmek oldukça önemli bir artıydı. Zira şikâyetler Divân'da görülüyordu. Belgelerde karşılaştı̆̆ımız sonuç ise Bosna'da yaşayan kadınlar açısından tam tersi yöndeydi. Bir belge dışında tüm kadınların şikâyetini iletmek için Bosna'dan geldiği belirlenmiştir. Bu durum kadınların haksızlık karşısında haklarını aramaları ve kendilerine verilmiş olan bir hakkı sonuna kadar kullanmaları açısından oldukça önemliydi.

Kadınlar, şikâyetlerini iletmede bizzat kendileri tarafından iletilmesini daha uygun görmüş olmalılar. Bu durum uğradıkları haksızlığın kökten çözülmesi için çaba harcadıklarını

bâbında emr-i şerîfim ricâ eyledikleri ecilden mahallinde şer'ile görülmek içün yazılmışdır." BOA, A.DVNS.AHK.BN.d.0003, Sayfa No: 83, Hüküm No: 2.

${ }^{35}$ BOA, A.DVNS.AHK.BN.d.0003, Sayfa No: 94, Hüküm No: 2, Sayfa No: 106, Hüküm No: 2.

${ }^{36}$ BOA, A.DVNS.AHK.BN.d.0003, Sayfa No:, 60, Hüküm No: 4.

37 "Fatma nâm hâtûn ile Halil ve Züleyha ve Zeyneb nâm yetimler rikâb-1 hümâyûnuma 'arz-1 hâl sunub mezbûre Fatma'nın zevcînden ve mezbûrların babalarından muntakil Mehmed Şehrî dimekle ma'rûf kimesne zimmetinde bâ-temessük üç bin guruş alacak hakları olub bundan akdem mezbûr âsitânede iken meblağ-1 mezbûr kendünden taleb olundukda mücerred ibtâl-1 hakk sevdâsiyla bugün yarın deyû 'avk ve te'hîr iderek âsitâne-i sa'âdetimden firâr ve varub eyâlet-i Bosna'da Uskupyeli Mehmed Paşa'nın kethüdâlık hidmetinde olub meblağ-ı merkûm mektûb ile taleb olundukda dahî kezâlik ta'allül ve gadr murâd eyledügün bildürüb çavuş mübâşeretiyle merkûm Mehmed âsitâne-i 'aliyyeme ihzâr olunmak bâbında sen ki Bosna vâlisi vezîr-i müşâru'n-ileyhsin sana hitâben emr-i şerîfim ricâ eyledikleri ecilden ta'yîn olunan çavuş mübâşeretiyle mezkûr Mehmed husemâlariyla li-eclil murâfa'a âsitâne-i 'aliyyeme ihzâr olunmak içün yazılmışdır Fî evâhir-i Za (Zi'l-ka'de) Sene 179" BOA, A.DVNS.AHK.BN.d.0003, Sayfa No: 54, Hüküm No: 1. 
göstermektedir. Kadınlar, erkekleri oldukça yüksek oranlarda şikâyet etmişlerdir. Şikâyet edilen erkeklerle daha fazla oranla bir akrabalıklarının olmadığı görülmüştür.

Divân'da kadınların en çok şikâyet ettiği konular miras, arazi gasbı, mülk gasbı ve alacakverecektir. Bu durum kadınların özellikle kendi paylarına düşen maddi getirilere oldukça önem verdikleri anlamını çıkarmamıza ve ekonomik alanda yer aldıklarını bize göstermektedir.

Kadınlar şikâyet eden olabildikleri gibi şikâyet edilen tarafta da olabilmişlerdir. Kadınlar, arazi gasbı, miras malına müdahale, muhtelif konular (haksız talep, kanuna aykırı satış işlemi, mehir) ve mülk gasbı konularında şikâyet edilmişlerdir. Tüm bu şikâyetler açısından bakıldığında kadınlar açısından maddi getiriler oldukça önem arz etmiş ve bu getirilere hakkı olmasa da sahip olmaya çalışmışlardır.

Sorunların çözümü noktasında Kadılar merkez tarafından birinci, Vali ise ikinci muhatap kabul edilmiştir. Hükümlerin birlikte gönderildiği belgelerde Kadı, Vali ile birlikte en fazla sorumluluk yüklenen olmuştur.

Sorunun çözümü noktasında Divân sorunun en çok mahallinde çözümünü istemekteydi. Zira mahalli birimlerde yargılama işini yapan kadılar bulunmakta ve işleyişin devamı için bu yöntem tercih edilmektedir. Eğer mahalline havale etmezse şikâyetin çözümü ile ilgili ya karar verilmekte ya da şikâyetin içeriğine göre çavuş marifetiyle şikâyet edilenin yakalanarak Divân'a getirilmesi suretiyle sorunun çözümüne çalışılmaktaydı.

\section{KAYNAKÇA}

Bâb-1 Asâfî Dîvân-1 Hümâyûn Sicilleri Dizisi, Bosna Ahkâm Defterleri, 3 Numaralı Bosna Ahkâm Defteri.

Açık, T. (2015). Toplumsal Cinsiyet Bağlamında Osmanlı Hukukunda Kadından Eşkıya Olup Olamayacağına Dair Bir Tartışma: Havva Hatun Örneği, Karadeniz Araştırmaları Enstitüsü Dergisi, 1(1): 35-94.

Akyüz, J. (2007). Osmanlı Kadınlannın Hukuksal Haklarını Kullanımı Hakkında Bazı Değerlendirmeler, Hacettepe Üniversitesi Türkiyat Araştırmaları Dergisi, (6): 75-91.

Aydın, M. A. (2003). Mehir. Türkiye Diyanet Vakfi İslam Ansiklopedisi, (28): 389-391.

Bayhan, V. (2012). Beden Sosyolojisi ve Toplumsal Cinsiyet, Doğu-Batı Düşünce Dergisi, 16(63): 147-164.

Berktay, F. (2015). Tarihin Cinsiyeti. (Beşinci Basım), İstanbul: Metis Yayınları.

Cin, H. (1979). Eski ve Yeni Türk Hukukunda Tarım Arazilerinin Miras Yoliyle İntikali. Ankara: Ankara Üniversitesi Hukuk Fakültesi Yayınları.

Efe, A. (2011). İslam Miras Hukukunda Kadın-Erkek Hisselerinin Farklı Oluşu Üzerine Bir Değerlendirme, İslam Hukuku Araştırmaları Dergisi, (18): 157-168.

Emecen, F. M. (2005). Osmanlı Divanının Ana Defter Serileri: Ahkâm-1 Miri, Ahkâm-1 Kuyûd-1 Mühimme ve Ahkâm-1 Şikâyet, Türkiye Araştırmaları Literatür Dergisi, 3(5): 107-139. 
Emecen, F. M. (2011). Osmanlı Klasik Çağında Hanedan Devlet ve Toplum. (Editör) Koçal, A.: Osmanlı Divanının Ana Defter Serileri: Ahkâm-ı Miri, Ahkâm-ı Kuyûd-ı Mühimme ve Ahkâm-ı Şikâyet içinde (ss.111-157) İstanbul: Timaş Yayınları.

Faroqhi, S. (2000), Modernleşmenin Eşiğinde Osmanlı Kadınları. (Editör) Zılfı, M. C.: 18. Yüzyıl Anadolu Kırsalında Suç, Kadınlar ve Servet içinde (ss.8-26) İstanbul: Tarih Vakfı Yurt Yayınları.

Göçek, F. M., ve Baer, M. D. (2000). Modernleşmenin Eşiğinde Osmanlı Kadınları. (Editör) Zılfı, M.C.: 18. Yüzyıl Galata Kadı Sicillerinde Osmanlı Kadınlarının Toplumsal Sınırları içinde (s. 48-63). İstanbul: Tarih Vakfı Yurt Yayınları.

Gümrükçüoğlu, S. O. (2012). Şikâyet Defterlerine Göre Osmanlı Teb'asının Şikâyetleri, Ankara Üniversitesi Hukuk Fakültesi Dergisi, 61(1): 175-206.

Gürhan, V. (2017a).18. Yüzyıl Osmanlı Toplumunda Kadın ve Hukuk: Amid Mahkemesi'nde Kadınların Hak Arama Süreçlerine Dair Bazı Değerlendirmeler, İnsan ve Toplum Bilimleri Araştırmaları Dergisi, 6(3): 1644-1664.

Gürhan, V. (2017b). Kadınların Dîvân-ı Hümâyun'a Şikâyet Hakkını Kullanmaları Üzerine Bazı Değerlendirmeler (Diyarbekir Eyaleti 1 Numaralı Ahkâm Defterine Göre), Tarih Okulu Dergisi (TOD), (32): 323-347.

Işık, Z. (2018). Osmanlı İmparatorluğu'nda Kamusal Alanda Cinsiyet ve Toplumsal Cinsiyet Kimliğiyle Kadın (1839-1900): Çorum Şer'iyye Mahkemesi Örneği, bilig, Türk Dünyası Sosyal Bilimler Dergisi, (85): 25-56.

İmber, C. (2000). Modernleşmenin Eşiğinde Osmanlı Kadınları. (Editör) Zılfı, M.C.: Kadınlar, Evlilik ve Mülkiyet: Yenişehirli Abdullah'ın Behcetü'l-Fetâvâ'sında Mehr içinde (ss.77-100) İstanbul: Tarih Vakfı Yurt Yayınları.

İnalcık, H. (1988). Şikâyet Hakkı: Arz-1 Hal ve Arz-1 Mahzarlar, Osmanlı Araştırmaları, (7-8): 3354 .

İnalcık, Ş. (1948). İbn-i Hacer'de Osmanlılara Dair Haberler, Dil Tarih Coğrafya Fakültesi Dergisi, 6(3): 189-195.

Keskin, F. ve Ulusan, A. (2016). Kadının Toplumsal İnşasına Yönelik Kuramsal Yaklaşımlara Dair Bir Değerlendirme, Akdeniz İletişim Dergisi,(26): 47-69.

Kınalızâde Ali, Ahlâk-ı Alâ-i. haz. Hüseyin Algül, Tercüman 1001 Temel Eser.

Kovacks, N. E. (2012). 17. Yüzyılda Divân-ı Hümayun'un Şikâyet Defterleri: Osmanlı Coğrafyası Kültürel Arşiv Mirasının Yönetimi ve Tapu Arşivlerinin Rolü Uluslararası Kongresi Bildirileri, 21-23 Kasım 2012, İstanbul, Türkiye.

Koyuncu Kaya, M. (2018). Tanzimat Öncesi Osmanlı Toplumunda Cinsiyet, Mahremiyet ve Sosyal Hayat. (Editör) Koyuncu Kaya, M ve Yılmaz B.: Osmanlı Kadını ve Çalışma Hayatı içinde (s. 289-303). Ankara: Türkiye Diyanet Vakfı Yayınları.

Mumcu, A. (2007). Divan-ı Hümayun. (1.Basım), Ankara: Phoenix Yayınları. 
Öz, M. (2017). Kanun-ı Kadimin Peşinde Osmanlı'da Çözülme ve Gelenekçi Yorumcuları. (7.basım), İstanbul: Dergâh Yayıncılık.

Özbay, C. (2012). Türkiye'de Hegemonik Erkekliği Aramak, Doğu-Batı Düşünce Dergisi, 16(63):185-204.

Özel, A. (1988). Ahkâm. Türkiye Diyanet Vakfı İslâm Ansiklopedisi, (1):550-551.

Özgişi, T. (2014). Osmanlı Adalet Sisteminde Bireysel Başvuru Hakkı, Yalova Üniversitesi Sosyal Bilimler Dergisi, (8): 52-66.

Sahillioğlu, H. (1988). Ahkâm Defteri. Türkiye Diyanet Vakfi İslam Ansiklopedisi, (1): 551.

Suzuki, T. (1987). Osmanlılarda Organik Bir Yapı Olarak Toplum Görüşünün Gelişmesi Osmanlı Sosyal Düşünce Tarihinin Bir Yönü, ODTÜ Gelişme Dergisi, 14(4): 373-396.

Şimşir, N. (2015). Ahkâm Defterleri'nin Tarihi Kıymeti ve 107 No'lu Anadolu Ahkâm Defteri'ndeki İzmir ile İlgili Hükümler, Tarih İncelemeleri Dergisi, 9(1): 357-390.

Taş, H. (2007). Osmanlıda "Şikâyet Hakkı"nın Kullanımı Üzerine Düşünceler, MEMLEKET Siyaset Yönetim, 2(3): 186-204.

Tuğluca, M. (2012). Bir Balkan Şehri Olarak Üsküp'te Şikâyet Hakkının Kullanımı ve Şikâyet Mekânizması, Motif Akademi Halkbilimi Dergisi, 2012(2): 107-128.

Tuğluca, M. (2016). Osmanlı Devlet-Toplum İlişkisinde Şikâyet Mekanizması ve İşleyiş Biçimi. (1.Basım), Ankara: Türk Tarih Kurumu.

Tursun Bey, Tarih-i Ebu'l-Feth. haz. Ahmet Tezbasar, Tercüman 1001 Temel Eser.

Vatandaş, C. (2007). Toplumsal Cinsiyet ve Cinsiyet Rollerinin Algılanışı, Sosyoloji Konferansları Dergisi, (35): 29-56.

Yılmaz, İ. (2012). Osmanlı Kadın Tarihine İlişkin Birkaç Not, Kadın Araştırmaları Dergisi, (10): 6181.

Zarinebaf-Shahr, F. (2000). Modernleşmenin Eşiğinde Osmanlı Kadınları. (Editör) Zılfı, M.C.: Osmanlı Kadınları ve 18. Yüzyılda Adalet Arama Geleneği içinde (s. 250-260). İstanbul: Tarih Vakfı Yurt Yayınları. 